\title{
Deconstruction of Lignin: From Enzymes to Microorganisms
}

\author{
Jéssica P. Silva ${ }^{1}$, Alonso R. P. Ticona ${ }^{1}{ }^{1}$, Pedro R. V. Hamann ${ }^{1}$, Betania F. Quirino ${ }^{2} \mathbb{D}$ and Eliane F. Noronha ${ }^{1, *}$ \\ 1 Enzymology Laboratory, Cell Biology Department, University of Brasilia, 70910-900 Brasília, Brazil; \\ wpinheiro.jessica@gmail.com (J.P.S.); alonso.poma.t@gmail.com (A.R.P.T.); \\ pedror_hamann@hotmail.com (P.R.V.H.) \\ 2 Genetics and Biotechnology Laboratory, Embrapa-Agroenergy, 70770-901 Brasília, Brazil; \\ betania.quirino@embrapa.br \\ * Correspondence: enoronha@unb.br; Tel.: +55-61-3307-2152
}

Citation: Silva, J.P.; Ticona, A.R.P.;

Hamann, P.R.V.; Quirino, B.F;

Noronha, E.F. Deconstruction of

Lignin: From Enzymes to

Microorganisms. Molecules 2021, 26,

2299. https://doi.org/10.3390/

molecules 26082299

Academic Editor: Claudio Gioia

Received: 26 February 2021

Accepted: 26 March 2021

Published: 15 April 2021

Publisher's Note: MDPI stays neutral with regard to jurisdictional claims in published maps and institutional affiliations.

Copyright: (c) 2021 by the authors. Licensee MDPI, Basel, Switzerland. This article is an open access article distributed under the terms and conditions of the Creative Commons Attribution (CC BY) license (https:// creativecommons.org/licenses/by/ $4.0 /)$.

\begin{abstract}
Lignocellulosic residues are low-cost abundant feedstocks that can be used for industrial applications. However, their recalcitrance currently makes lignocellulose use limited. In natural environments, microbial communities can completely deconstruct lignocellulose by synergistic action of a set of enzymes and proteins. Microbial degradation of lignin by fungi, important lignin degraders in nature, has been intensively studied. More recently, bacteria have also been described as able to break down lignin, and to have a central role in recycling this plant polymer. Nevertheless, bacterial deconstruction of lignin has not been fully elucidated yet. Direct analysis of environmental samples using metagenomics, metatranscriptomics, and metaproteomics approaches is a powerful strategy to describe/discover enzymes, metabolic pathways, and microorganisms involved in lignin breakdown. Indeed, the use of these complementary techniques leads to a better understanding of the composition, function, and dynamics of microbial communities involved in lignin deconstruction. We focus on omics approaches and their contribution to the discovery of new enzymes and reactions that impact the development of lignin-based bioprocesses.
\end{abstract}

Keywords: lignin; bacteria; biodegradation; auxiliary activities; metagenomics; metaproteomics; metatranscriptomics

\section{Introduction}

The conversion of lignocellulosic biomass into biofuels and chemicals has gained interest because of its potential application in biorefineries as a green platform. Lignocellulosic biomass is mainly composed of lignin and polysaccharides (i.e., cellulose, hemicellulose, and pectin), arranged in plant cell walls. Cellulose is a homopolymer, composed of Dglucose monomers joined by linear $\beta$ (1-4) linkages. Hemicellulose is also a sugar polymer, but it is composed of different monosaccharide molecules mainly joined by $\beta-1,4$ glycosidic linkages. Among the sugars that compose hemicellulose, D-xylose, D-mannose, and arabinose are present. Hemicellulose polymers are strongly interlinked through covalent and non-covalent bonds, and also linked to lignin, which together with cellulose will form the recalcitrant lignocellulosic matrix [1,2]. In the plant cell wall, lignin is linked to the carbohydrate moiety via the ester linkage. This association gives the plant cell wall greater strength and impermeability [3]. Lignin is formed by radical coupling reactions involving the three main phenylpropane units: p-hydroxyphenyl $(\mathrm{H})$, guaiacyl $(\mathrm{G})$, and syringyl (S), linked by $\mathrm{C}-\mathrm{C}$ and $\mathrm{C}-\mathrm{O}$ linkages $[4,5]$.

Lignin is the main plant cell wall component responsible for recalcitrance [6]. Thus, pretreatment is an essential step for removing lignin in the process of lignocellulosic biomass conversion into biofuels $[7,8]$. The high carbon/oxygen ratio and the natural abundance of lignin make it a promising feedstock material for biological conversion into value-added products [9]. In addition to the biofuel industry, lignin may also be found as a by-product from wood-biomass in industrial processes for paper and pulp production. 
At least 75,000 tons of kraft-lignin were commercialized in 2018, and for the year 2025, 250,000 tons are expected [10].

The efficient degradation of lignin by white-rot basidiomycete fungi has been extensively studied [11,12]. Bacteria are also capable of deconstructing lignin [5,13], but they are less studied in comparison to fungi $[12,14]$. Recently, bacteria have been attracting great attention due to their high adaptability and biochemical versatility. Furthermore, bacteria have metabolic pathways that convert lignin and its derivates into products of biotechnological interest such as lactic acid, pyruvate, vanillin, lipids, polyhydroxyalkanoates (PHA), and cis-muconic acid (cis, cis-MA) [15,16].

In nature, lignin is deconstructed by the concerted efforts of microbial communities, rather than isolate microorganisms. Therefore, the strategy of studying the microbial community may provide a broader comprehension of the process of lignin deconstruction. In natural environments, different microorganisms in the microbial community operate synergistically through the secretion of a variety of biocatalysts. Although in nature cooperation between different microorganisms is common, in the laboratory, not all organisms are easily cultured, which is an obstacle to adapting the natural synergistic lignin deconstruction to its bioconversion in industrial processes. However, investigation of natural microbial communities using culture-independent approaches (e.g., metagenomics, metatranscriptomics, and metaproteomics) may deliver a detailed description of the processes and enzymes involved. Thus, the study of lignin-degrading microbiomes (e.g., forests, animals' digestive tract, and sewage $[17,18]$ ) may be crucial to the development of efficient industrial processes for the use of ligninolytic feedstocks.

In the present review, we explore the contribution of omics approaches in discovering/describing new enzymes and microorganisms in microbiomes adapted to degrade lignin. Primarily, we focus on ligninolytic enzymes belonging to the auxiliary activities (AA) family, with emphasis on their impact on lignin valorization in industrial processes.

\section{Lignin}

\subsection{Structure and Composition of Natural Lignin}

Lignin is a phenolic macromolecule of high molecular weight, composed of three main units of phenylpropane (monolignols): coniferyl alcohol, sinapyl alcohol, and $p$-coumaryl alcohol (Figure 1). When incorporated into the lignin structure, these monomers are termed p-hydroxyphenyl (H), guaiacyl (G), and syringyl (S) units, respectively [19-21]. In addition to these three main units, other subunits are present in the lignin structure. Among them are ferulic acid, ferulates, coniferaldehyde, synapaldehyde, 5-hydroxyiconiferyl alcohol, and acylated monolignols that contain acetate, $p$-coumarate [21-23].
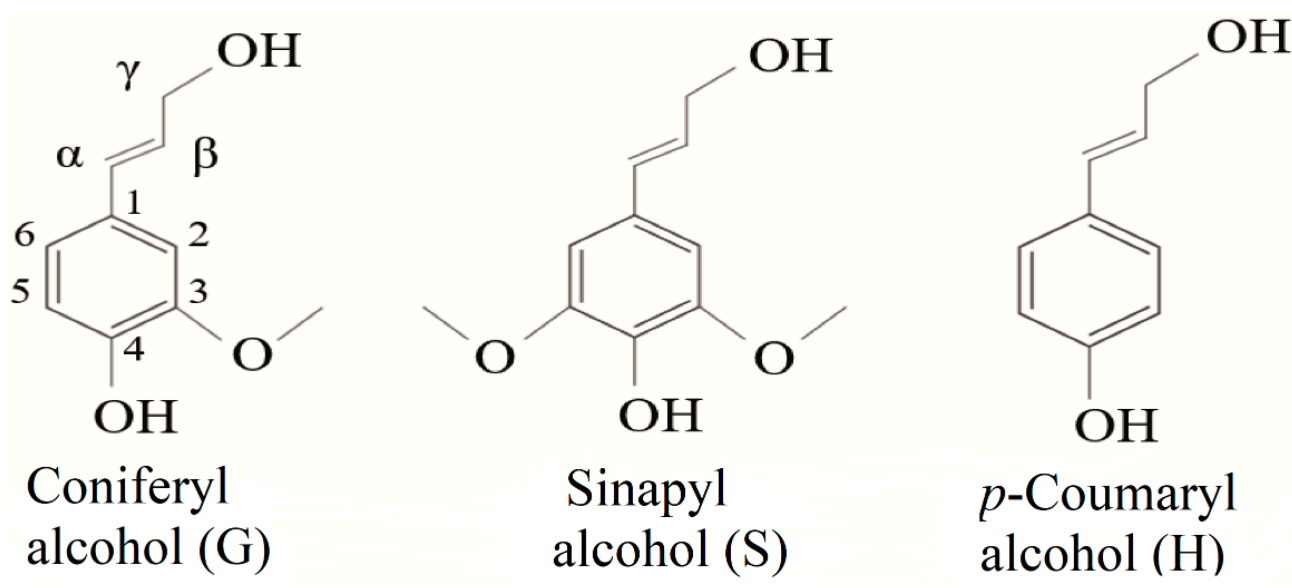

Figure 1. Chemical structures of the three monomeric precursors of the lignin macromolecule. 
Depending on its origin, lignin can be classified into three main groups: softwood, hardwood, and grass lignins. Softwood lignins are mainly composed of guaiacyl units, and thus are classified as G-type lignin. Hardwood lignins are mainly composed of different proportions of guaiacyl-syringil (GS-type) [24,25]. Grass lignins have a mixture of the three aromatic units (HGS), and contain a higher proportion of $p$-coumaryl alcohol (H)-derived units than other lignin types [26,27]. The highest proportion of lignin is found in softwoods (24-33\%), while hardwoods and grasses have a smaller amount $(\sim 15-28 \%)[4,28]$.

The linkages between phenylpropane units can be ether bonds $\left(\beta-\mathrm{O}-4^{\prime}, 4-\mathrm{O}-5^{\prime}\right)$ or carbon-carbon bonds $\left(5-5^{\prime}, \beta-5^{\prime}, \beta-\beta^{\prime}, \beta-1^{\prime}\right)$ usually called condensed bonds (Figure 2). The relative abundance of these linkages depends on the type of monomer present in the lignin structure. For example, G-type lignins contain more resistant linkages $(\beta-5,5-5)$ than S-rich lignins that are less condensed-bonded through ether bonds [23].<smiles>COc1cc(C[10BH]Oc2c(O)cc(C)cc2OC)ccc1O</smiles>

$\beta-\mathrm{O}-4$<smiles>COc1cc(C)cc(Sc2cc(C)cc(OC)c2O)c1O</smiles>

$\mathrm{OH}$<smiles>CCCc1ccc(Oc2cc(CCC)cc(OC)c2O)c(OC)c1</smiles><smiles>COc1ccc(C=C(C)C(C)C)cc1OC</smiles>
$\beta-\beta$

$5-5$<smiles>COc1cc(CC(C)C)ccc1O</smiles>

Figure 2. Typical linkages found in the structure of natural lignin; ether bonds $\left(\beta-\mathrm{O}-4^{\prime}, 4-\mathrm{O}-5^{\prime}\right)$ and condensed bonds $\left(5-5^{\prime}, \beta-5^{\prime}, \beta-\beta^{\prime}, \beta-1^{\prime}\right)$.

In the plant cell wall, lignin is covalently linked to the hemicellulose matrix, forming the lignin-carbohydrate complex (LCC). Among the types of linkages that are formed in the LCC, there are phenyl glycosides, benzyl ester, and ferulate or deferulate esters that are linked to lignin in 4-OH and 4-O positions $[29,30]$. Phenyl-glycoside bonds are one of the most common linkages in the LCC complex and are established between the carbohydrate reducing ends and the phenolic terminal groups of the lignin macromolecule. The benzyl ester linkages connect the lignin and carbohydrate moieties through the uronic 
acid of the carbohydrates and the hydroxyl group of the lignin. Ferulate or deferulate esters form most of the LCC linkages in grasses [31]. Ferulate mediates the crosslinks between polysaccharide-polysaccharide and polysaccharide-lignin. Crosslinks make the lignin physically close to the cell wall polysaccharides in such a way that lignin blocks the access of enzymes to the polysaccharides $[19,26]$.

\subsection{Technical Lignins}

Technical lignins are produced as by-products in the pretreatment of lignocellulose procedures to obtain the carbohydrate moiety. These procedures include physical, chemical, and physicochemical methods, which result in a liquid residue known as black liquor, mainly composed of lignin, carbohydrates, and ash. Processing methods such as kraft, lignosulfonate, soda, organosolv, and hydrolyzed lignin are widely used, and each lignin produced is unique in terms of chemical structure, impurity profile, polydispersity, and molecular weight [32-34].

Technical lignin has been used for the development of products such as binders, dispersants or emulsifiers, and sequestrants. Almost $90 \%$ of commercial lignin products in the world are lignosulfonates, often used as polymeric anionic dispersants. Technical lignin has also been used for civil engineering applications such as soil stabilization, asphalt stabilization, and cement additives [35-37].

The kraft procedure is the primary pulping process and uses a mixture of sodium hydroxide $(\mathrm{NaOH})$ and sodium sulfide $\left(\mathrm{Na}_{2} \mathrm{~S}\right)$ solution at high temperatures $\left(150-180{ }^{\circ} \mathrm{C}\right)$, which breaks ether bonds in lignin through an episulfide intermediate. During cooking, lignin is degraded into fragments of different molecular weights and is dissolved into the pulping liquor. After separating cellulose by filtration, the lignin and remaining hemicellulose in the liquid phase (black liquor) can be used in industrial processes. In modern pulp mills, the lignin present in black liquor is incinerated to supply energy for the mill. Isolation of lignin from black liquor for conversion into valuable products such as biofuel or a chemical compound might be an interesting alternative. Indeed, a lignin isolation procedure from black liquor known as lignoboost has been introduced. This procedure begins with adjusting the $\mathrm{pH}$ (up to 9.5) of the black liquor with the addition of carbon dioxide $\left(\mathrm{CO}_{2}\right)$. In the next step, the recovered lignin is re-slurried using sulfuric acid $\left(\mathrm{H}_{2} \mathrm{SO}_{4}\right)$ to $\mathrm{pH} 2$, and finally, the lignin is isolated by filtration [38,39].

Kraft lignin shows different properties, distinguishing it from native lignin and other technical lignins. For instance, it has a significant increase of phenolic hydroxyl groups due to extensive cleavage of $\beta$-aryl bonds during the cooking process; furthermore, condensed structures and biphenyl are formed as a result of the severe procedure conditions. Lignin condensation usually occurs by the formation of new intermolecular $\mathrm{C}-\mathrm{C}$ bonds between lignin fragments. Indeed, $C-C$ bonds such as $\beta-\beta$ and $\beta-5$ linkages are more difficult to disrupt than $\mathrm{C}-\mathrm{O}$ bonds ( $\beta$-aryl ether linkages). The degree of lignin condensation is important as it affects lignin recovery after biomass pretreatment. Preventing $\mathrm{C}-\mathrm{C}$ bond formation during pretreatment reaction is an important positive variable for downstream utilization of lignin $[30,34,40]$.

Lignosulfonates are obtained as by-products of sulfite cooking, in which delignification of biomass occurs by the addition of sulfite $\left(\mathrm{SO}_{3}{ }^{2-}\right)$ and bisulfite $\left(\mathrm{HSO}_{3}{ }^{-}\right)$. In this procedure, lignin is sulfonated, degraded, and solubilized. Lignosulfonates contain a large number of functional groups such as carboxylic, sulfur, and phenolic hydroxyl groups. Moreover, it presents distinctive physical and chemical characteristics such as solubility in water, high ash content, and relatively high molecular weight [40].

In the organosolv process, a mixture of organic solvent/solvents and water are added to the biomass, and these are essentially cooked at high temperatures $\left(190^{\circ} \mathrm{C}\right)$. Solvents such as ethanol, formic acid, acetic acid, and peroxiorganic acids are commonly used in this process. After this procedure, lignin is separated via solubilization. The lignin obtained by this process is less modified. Therefore, the main features of organosolv lignins are low 
molecular weight, high chemical purity, and the presence of many reactive side chains available for further chemical reactions, however, it shows poor solubility in water [38,39].

Depending on the conditions, and nature of the procedure that the lignocellulose biomass is subjected to, the resulting lignin might undergo irreversible repolymerization. In this case, lignin's innate recalcitrance is enhanced, making it more challenging to produce value-added chemicals from it. In some cases, significant amounts of inhibitory products such as phenolic acids, furfurals, 5-hydroxymethylfurfural, and aldehydes are generated, and these can negatively impact downstream processes such as cellulose hydrolysis and fermentation [41].

Ionic liquids (ILs) are green solvents that can also be used for biomass pretreatment. In this case, dissolution of lignin contained in lignocellulosic biomasses is accomplished by using organic salts (i.e., alkylbenzenesulfonate, $N$-methylimidizole, and dimethylsulfoxide) that remain as liquids at relatively low temperatures $\left(100{ }^{\circ} \mathrm{C}\right)$. Although ILs are not yet available at an industrial scale, there is growing interest in the utilization of ILs for the processing of biomass. IL pretreatments tend to preserve $\beta-\mathrm{O}-4$ linkages in the lignin structure, maintaining similar properties to organosolv lignin. Lignin can be recovered from the ILs by precipitation via the addition of non-solvents such as water or acetonitrile $[30,33]$.

\section{Bacterial Enzymes for Lignin Deconstruction}

Degradation and modification of lignin by bacteria involve a repertoire of redox-active enzymes classified in auxiliary activity (AA) families, according to the Carbohydrate-Active enZYmes (CAZy) Database [42]. These auxiliary activities involved in lignin breakdown primarily include the AA1 family, which contains laccases; and the AA2 family, which includes lignin-active class-II peroxidases. These enzymes alongside glycoside-hydrolases work in synergism to degrade lignocellulose (Figure 3). Additionally, other families show a correlation with oxidation or reduction of lignin-derived compounds such as the AA4 family, which includes vanillyl-alcohol oxidases; the AA5 family, which contains glyoxal oxidases/alcohol oxidases; and the AA6 family, which includes 1,4-benzoquinone reductases. Families AA3 and AA7 also show members potentially involved in lignin degradation and modification through Fenton reactions [43].

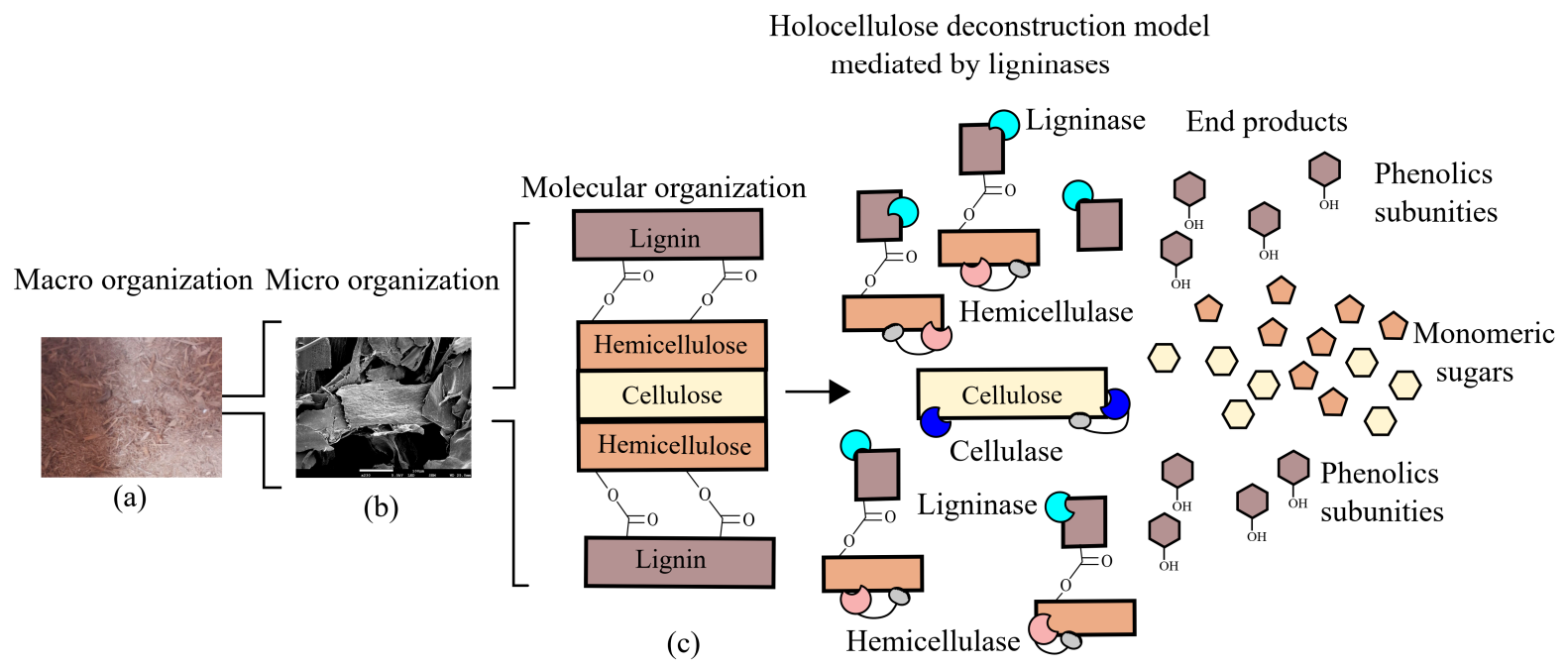

(d)

Figure 3. Cooperative model of lignin active enzymes and holocelullases in lignocellulosic biomass deconstruction. (a) Macro organization (sugarcane bagasse) and (b) micro organization (scanning electron microscopy) images are courtesy of Hamann P.R.V. (c) Carbohydrates and lignin organization in the plant cell wall. (d) cooperative activity of hemicellulases, cellulases, and ligninases to deconstruct lignocellulose. 
The basic mechanism of bacterial lignin deconstruction is analogous to that previously described for filamentous fungi, in which enzymes with oxidative activity present a central role. Enzymes are commonly described as being involved in lignin degradation in fungi such as laccases (E.C 1.10.3.2) and lignin peroxidases (E.C 1.11.1.7), and manganese peroxidases (E.C 1.11.1.13) are also present in bacteria [44,45]. Following Cazy database categorization, based on protein sequence and functional validation, most of the enzymes involved in lignin and aromatic compound oxidation are grouped in auxiliary activity (AA) families I and II. The AAI group comprises laccase/di-phenol:oxireductases/ferroxidases (EC 1.10.3.2), laccase-like multicopper oxidases (EC 1.10.3.-), and ferroxidases (EC 1.10.3.2). Group AA2 includes ascorbate peroxidases (EC 1.11.1.11), versatile peroxidases (EC 1.11.1.16), lignin peroxidases (EC 1.11.1.14), peroxidases (EC 1.11.1-), cytochrome-c peroxidases (EC 1.11.1.5), and manganese peroxidases (EC 1.11.1.13).

Laccases are multi-copper oxidases displaying activity against monophenols and compounds containing $p$-diphenol structures $[46,47]$. One of the first evidences of laccase activity produced by bacteria was observed for Azospirillum lipoferum, an alphaproteobacteria obtained from rice rhizosphere. These enzymes displayed oxidative activity against $p$-phenylenediamine, hydroquinone, L-DOPA (L-3,4-dihydroxyphenylalanine), syringaldazine (4-hydroxy-3,5-dimethoxy-benzaldehyde azine), and ABTS (2,2' -azinobis(3-ethylbenzothiazoline-6-sulfonic acid)) [48]. The enzyme responsible for the laccase activity was later purified and characterized as a multimeric protein. Similar findings have been described for fungal laccases, which can be monomeric, dimeric, or tetrameric [46].

Extremophile bacteria can also be laccase producers. Rezaei et al. (2017), purified a monomeric laccase $(75 \mathrm{kDa})$ produced by the halotolerant bacterium Aquisalibacillus elongatus [49]. The purified enzyme showed activity against a variety of substrates including polyphenols such as tannic acid and monomeric phenols such as catechol, gallic acid, and guaicol [49]. In another report, Yu Chen et al. (2013) obtained a trimeric thermostable laccase from the thermophilic actinomycete Thermobifida fusca, produced using sugarcane biomass as the substrate. The purified enzyme had maximum activity at $60^{\circ} \mathrm{C}$, and exhibited oxidizing activity against the dyes p-phenylenediamine, and 2,6-dimethylphenylalanine [50].

Manganese peroxidases $(\mathrm{MnP})$ contain a heme structure with a central manganese ion. These enzymes catalyze the reduction of substrates using $\mathrm{H}_{2} \mathrm{O}_{2}$ as an electron donor, catalyzing the oxidation of lignin [51,52]. Manganese peroxidases have been obtained from a great variety of bacteria. Oliveira et al. Oliveira (2009) reported the purification of MnPs from Bacillus pumilus, and Paenibacillus sp., isolated from wood-decaying material and paper mill effluent, respectively [51]. MnPs have also been identified in the alphaproteobacteria Aurantimonas manganoxydans and Erythrobacter sp. [52]. An MnP produced by Bacillus subtilis from decomposing natural rubber in soil was reported by Nayanashree and Thippeswarny (2015) [53]. Although there are a number of reports on bacterial MnPs, they are much less characterized in comparison to laccases.

Lignin peroxidases are a widely studied class of proteins from the fungus Phanerochaete chrysosporium. Enzymes from this class can catalyze the oxidation of lignin and phenolic related compounds using peroxide [4]. Their counterpart in bacteria has been reported in a variety of genera including those typically found dwelling in lignin-rich environments. For example, a Bacillus sp. isolate (CSA105) from a paper mill effluent was able to produce classic plant cell wall degrading enzymes (e.g., cellulases) as well as lignin-active enzymes including a lignin peroxidase [54]. Still, regarding the phylum firmicutes, Gomare et al. (2008) reported the production and purification of a lignin peroxidase from Brevibacillus laterosporus MTCC 2298. The reported LiP displayed activity against the industriallyrelevant dyes (i.e., methyl orange, and Blue-2B) [55].

Bacteria isolated from natural environments including actinobacteria have also been described as important players in lignin degradation mediated by LiP. Yee and Wood (1997) reported a LiP produced by Streptomyces viridosporum T7A with activity against 2,4dichlorophenol, a compound usually found in pesticides and herbicides, which can be an 
important environmental contaminant [56]. Similar results were reported for a $49.7 \mathrm{kDa}$ peroxidase from Streptomyces sp. AD001 that showed activity against 2,4-dichlorophenol [57].

In addition to the classical oxidases reported as presenting a central role in lignin degradation by bacteria, recent studies show other activities such as $\beta$-etherases enzymes, which are involved in lignin/phenolic compounds deconstruction/consumption. $\beta$-etherases cleave $\beta$-aryl ether bonds found in lignin and are receiving attention because they can degrade this kind of linkage in high-molecular-weight lignin. $\beta$-Etherase activity has been described for Sphingomonas paucimobilis SYK-6, and thus far it is one of the few enzymes with a non-oxidative mechanism against lignin [58].

One of the early studies on $\beta$-etherases was a report of the genes ligE and ligF coding for two $\beta$-etherases with similarities to the glutathione- $S$-transferase protein family in Sphingomonas paucimobilis SYK-6 [58]. Later, these $\beta$-etherases from S. paucimobilis were expressed in E. coli and shown to degrade high-molecular-weight lignin [58,59].

With the advent of new techniques to prospect new putative genes encoding ligninmodifying and deconstruction enzymes, and the development of more accurate protocols to identify products of lignin degradation and/or modification, it is expected that a more diversified group of proteins will be categorized as being involved in lignin biodegradation. Many reports of putative enzymes involved in lignin breakdown are based on the presence of proteins or sometimes gene expression when a microorganism is cultured in the presence of lignin or lignin-related compounds. However, more direct experimental data are still needed to validate the role of specific enzymes in lignin deconstruction. Examples include dioxygenases and veratryl alcohol oxidases, which do not have a widespread role in lignin and aromatic compound degradation in bacteria and require further validation of their role in lignin deconstruction.

\section{Approaches to Access Bacterial Community Structure and Functionality}

Metagenomics is a culture-independent approach that can be used to describe a microbiome in two different levels: structural and functional. At a structural level, a microbial community can be described regarding the microorganisms present, from phylumto species-level, in addition, ecological interactions and evolutionary aspects can be explored [60,61]. In contrast, functional metagenomics explores the bacterial community genomic diversity of a sample, allowing the identification of genes and biochemical pathways prevalent in a microbiome (Figure 4). The choice of the target environment for omics studies is essential for mining biocatalysts. As shown in Table 1, in natural or modified microbiomes where lignin degradation occurs naturally, a repertoire of bacteria and genes that are involved in lignin degradation has been identified.

Different experimental approaches can be used to access the structural and functional profiles of microbial communities. Metataxonomics, for example, is based on the sequencing of phylogenetic marker genes such as 16S rRNA, providing information about the structural composition of a bacterial microbiome, sometimes reaching the hierarchical level of species [62-64]. On the other hand, shotgun metagenomics is an undirected sequencing of all the microbial DNA in a sample, allowing access to both the structural and functional community profile. Functional information can also be accessed through phenotypic screening, which includes the construction of metagenomic libraries, and the use of different techniques to identify genes with the desired function such as activity-based screening [65-67]. In addition to direct analysis of environmental samples using DNA sequencing techniques, culture-enrichment is a powerful tool to establish microbial consortia with desired properties. This technique basically consists of cultivating environmental communities on desired substrates such as lignin and/or lignocellulosic materials under specific conditions, thus providing the enrichment of microorganisms with the desired function. This selected microbial community is then subjected to the culture-independent methods previously described or the traditional culture-based ones. 


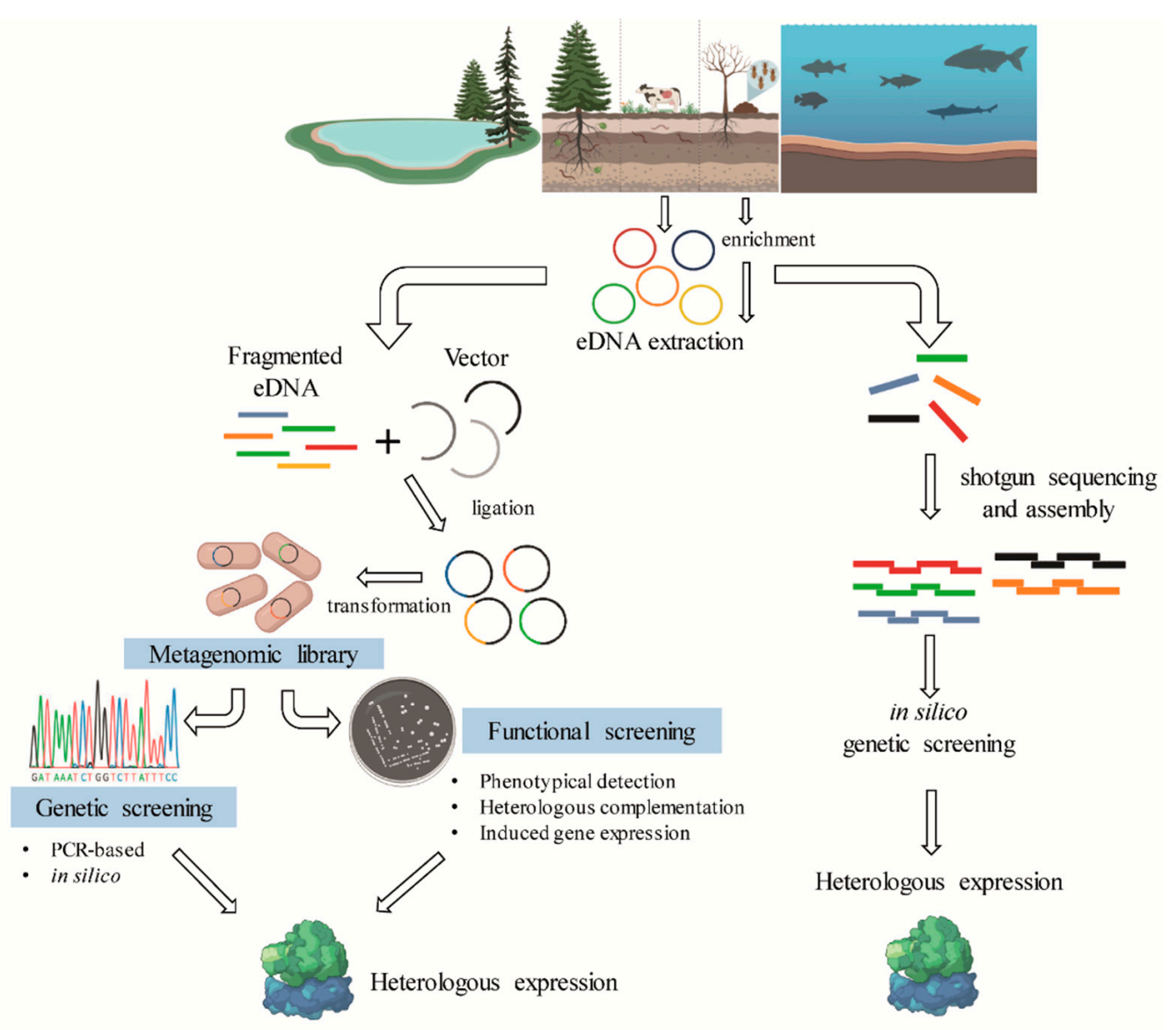

Figure 4. General scheme of the metagenomic strategies for the identification of lignin-degrading enzymes from different bacterial communities.

Table 1. Auxiliary activity families (AAs) present in different bacterial communities as surveyed from metaomics studies.

\begin{tabular}{|c|c|c|c|}
\hline DNA Source & $\begin{array}{c}\text { Bacteria Associated with Lignin } \\
\text { Degradation }\end{array}$ & AAs Families & References \\
\hline Brazilian Caatinga soil & Proteobacteria, Actinobacteria, Acidobacteria & AA1, AA3, AA7 & [68] \\
\hline Forest soil & $\begin{array}{l}\text { Proteobacteria, Acidobacteria, and } \\
\text { Actinobacteria }\end{array}$ & AA3 & [69] \\
\hline Soil & $\begin{array}{l}\text { Caulobacteraceae, Acidobacteria, } \\
\text { Solirubrobacterales, Elusimicrobia, } \\
\text { Nevskiales, and Cystobacteraceae }\end{array}$ & $\begin{array}{l}\text { AA1, AA3, AA4, AA5, AA6, and } \\
\text { AA7 }\end{array}$ & [70] \\
\hline Antarctic soil & $\begin{array}{l}\text { Geodermatophilus, Thermobispora, and } \\
\text { Amycolatopsis }\end{array}$ & $\mathrm{AA} 3, \mathrm{AA} 4$, and AA7 & [18] \\
\hline Agricultural soil & Proteobacteria & AA3, and AA6 & {$[71]$} \\
\hline Termite gut microbiome & $\begin{array}{l}\text { Legionella, Acinetobacter, and Pseudomonas, } \\
\text { Myxococcus, Streptomyces, and } \\
\text { Actinoplanes }\end{array}$ & $\mathrm{AA} 1, \mathrm{AA} 3, \mathrm{AA} 4, \mathrm{AA} 5$, and AA6 & [72] \\
\hline Arion gut microbiome & n.s. & $\mathrm{AA} 2, \mathrm{AA} 3, \mathrm{AA} 4$, and AA6 & [73] \\
\hline Folsomia gut microbiome & Proteobacteria and Actinobacteria & AA3, AA6, and AA7 & [74] \\
\hline Bovine rumen & $\begin{array}{l}\text { Prevotella, Bacteroides, Clostridium, } \\
\text { Fibrobacter, and Ruminococcus }\end{array}$ & AA6, AA5, AA4, AA7, and AA3 & [75] \\
\hline Camel rumen & $\begin{array}{l}\text { Firmicutes, Bacteroidetes, Spirochaetaes, } \\
\text { Fibrobacteres, and Proteobacteria }\end{array}$ & AA3, AA4, AA6, and AA7 & [76] \\
\hline Elephant feces & n.s. & AA4 and AA6 & [77] \\
\hline
\end{tabular}


In the next topic of this review, bacterial communities that use lignin as a carbon source and genes encoding lignin-modifying auxiliary activity (AAs) present in natural or enriched microbiomes will be described, with a special focus on omics techniques.

\subsection{Microbiomes Characterized Using Metagenomic Approaches}

\subsubsection{Soil}

As previously discussed, environmental samples are an interesting source of microorganisms specialized in lignin deconstruction. One such example is soil bacteria, which play an active role in deconstructing the litter deposited in the Brazilian Caatinga soil. In a study that analyzed metagenomic libraries sequences from this microenvironment, considerable genetic potential for the deconstruction of lignin was observed in which members of the phyla Proteobacteria, Actinobacteria, and Acidobacteria acted mainly through enzymes belonging to auxifamilies AA3, AA7, and AA1 [68].

In the topsoil of coniferous forests, the phyla Proteobacteria, Acidobacteria, and Actinobacteria with the potential to encode genes for auxiliary enzyme activities, especially those belonging to AA3 families, have also been identified [69]. Interestingly, in another study, Wilhelm et al. (2019) [70], also characterized this microbiome in North America through the association of stable isotope probing (SIP), 16S rRNA gene amplicon, and shotgun metagenomics. The SIP technique was used to label microorganisms capable of assimilating the ${ }^{13} \mathrm{C}$-labeled substrates (hemicellulose, cellulose, or lignin) in the different soil layers. The authors demonstrated that bacterial deconstruction of lignin seems to occur throughout the entire soil column, and not just in the upper layer. Different bacteria with ligninolytic potential were identified both in the organic layer and in deeper mineral layers (Table 1). Among them are new lignin degraders from mineral soils belonging to the noncultivable clades of Caulobacteraceae, Acidobacteria, Solirubrobacterales, Elusimicrobia, Nevskiales, and Cystobacteraceae. Likewise, the genes of the most abundant AA families (AA3, AA4, and AA6) were mainly from bacteria.

Antarctic soil microbial communities represent a genetic reservoir of cold-active ligninolytic enzymes. Bacteria belonging to the genera Geodermatophilus, Thermobispora, and Amycolatopsis exhibited potential for deconstructing lignin, with enzymes belonging to families AA7, AA3, and AA4, respectively, being the most prevalent [18].

Functional metagenomic analysis of a microbial community present in hydrocarboncontaminated agricultural soils has shown that these environments also harbor bacteria specialized in lignin deconstruction. Members of the phylum Proteobacteria were identified as the main group, having genes for enzymes with auxiliary activity belonging to families AA3 and AA6 [71]. In these different microbiomes, bacteria belonging mostly to the phyla Proteobacteria, Acidobacteria, and Actinobacteria are central lignin decomposers. These bacteria use a different set of enzymes to deconstruct the lignin structure (Table 1), and it is worth mentioning that AA3 probably plays a role in lignin deconstruction in the soil as it is constantly part of the group of the most abundant enzymes.

\subsubsection{Invertebrate Digestive Tract}

Bacterial communities inhabit a diversity of environments, and numerous bacteria live in association with invertebrate hosts such as termites, wood wasps, beetles, and woodfeeding roaches $[78,79]$. Insects play an important ecological role in the carbon cycle, and the breakdown of lignocellulosic fibers (e.g., wood, grass, and litter) [80]. Bacteria express and secrete carbohydrate-active enzymes in the invertebrate gut system, thus contributing to the digestion of lignocellulosic substrates [81].

To date, little is known about lignin degradation in the termite gut, whether it is performed by the termites themselves or mediated by unidentified gut bacterial communities involved in lignin degradation [82]. Although the majority of metagenomic studies of termite luminal fluid have shown no evidence for lignin degradation, some bacteria have been isolated and identified from termite gut such as Trabulsiella sp., Rhodococcus erythropolis, and Streptomyces, which have exhibited peroxidase and laccase activities [83-85]. 
Nevertheless, recent taxonomic and functional metagenomic analysis of gut microbiota of seven species of termites (subfamilies Syntermitinae, Nasutitermitinae, Apicotermitinae, and Termitinae) has revealed the presence of bacterial genes that encode enzymes that play a role in lignin deconstruction [72]. As a result, a set of CAZymes (CAZy database [86]), AA1, AA3, AA4, AA5, and AA6 families involved in the degradation and modification of aromatic compounds were detected in almost all termite species investigated. The most common bacterial genera harboring genes encoding for the AA1 family were Legionella, Acinetobacter, and Pseudomonas, for the AA5 family these were Myxococcus and Streptomyces, and for the AA7 family, it was Actinoplanes.

In another study of termites, Su et al. (2016), using 454 pyrosequencing of 16S rRNA, analyzed the microbiota gut of four species of termites (three species of wood-feeding termites and one species of a fungus-feeding termite) and Spirochaetes (11-55\%), Firmicutes (7-18\%), Bacteroidetes (7-31\%), and Proteobacteria (8-14\%) were detected as the main phyla for all four termites. Furthermore, based upon the automatically taxonomy-to-phenotype mapping, bacterial metabolic activities related to lignin degradation and modification of lignin-derived aromatic compounds were identified [87].

These findings show that the termite gut system contains bacteria whose genes encode enzymes for lignin degradation or modification, although their function in the termite gut remains unclear. Moreover, the bacterial communities differ between the midgut and hindgut segments (P1 to P5) of termites [88]. These differences may be related to oxygen availability. For instance, oxygen is low in the P3 segment, which may hinder oxidative degradation of lignin, while gut segments with aerobic conditions may harbor several species capable of lignin degradation [81].

In another study aiming to investigate the microbiota of the Asian long-horned beetle midgut, several bacterial reads with copper oxidase (Cu-oxidase) domains were searched in the protein family database (Pfam [89]), and many of these reads had a similarity to laccases, multicopper oxidases, and polyphenol oxidases. Additionally, a considerable number of annotated sequences had conserved domains with similarity to hypothetical proteins, which could represent uncharacterized laccase-type enzymes for lignin degradation. Furthermore, bacterial dye-decolorizing peroxidases that can cleave the $\beta$-aryl ether linkages in both syringyl and guaiacyl lignin in the presence of hydrogen-peroxide were detected. Genes for $\beta$-aryl ether degrading enzymes, classified as $\beta$-etherases or glutathione-S-transferases, were also identified [17].

A repertoire of lignocellulose-degrading enzymes has also been identified in the gut microbiome of the common black slug Arion. This study revealed more than 3383 CAZymes including multiple AAs families, associated with lignin degradation including members of the AA2, AA3, and AA4 families, which are involved in oxidative degradation, and the AA6 family, which catalyze the biodegradation of aromatic compounds such as monolignols [73].

Using shotgun sequencing and bioinformatics approaches, Agamennone et al. (2019) analyzed the gut microbiome associated with the soil invertebrate Folsomia candida. A total of 2004 genes encoding enzymes that degrade cellulose, starch, and lignin were detected. Among these, 1988 (99.2\%) were of bacterial origin and mainly originated from Proteobacteria (43\%) and Actinobacteria (36\%). Among the CAZyme families, 81 genes were identified as auxiliary activities and the most abundant were the family members of AA3 family (32\% of the total), AA6 (27\%), and AA7 (17\%). The repertoire of auxiliary activities identified suggested that the bacterial microbiome plays a role in the degradation or modification of lignin contributing to the adaptation of the invertebrate to life in the soil [74].

\subsubsection{Vertebrate Digestive Tract}

Bacterial CAZymes are essential to ruminants as they hydrolyze fibrous plant materials, which are utilized by host animals as energy sources [90]. Studies of the ruminal microbiome at the domain level established that $97.5 \%$ of sequences belong to bacteria, $1.3 \%$ 
to archaea, and $0.9 \%$ to eukaryotes [75]. The phyla Bacteroidetes, Firmicutes, Proteobacteria, and Fibrobacteres were identified as being involved in plant biomass degradation [75,91,92].

According to Jose et al. (2017), approximately $0.46 \%$ of AA families of the total number of CAZyme families are involved in bovine rumen plant biomass deconstruction. It should be noted that AAs, which are involved in lignin degradation and act in conjunction with other hydrolytic enzymes, were observed with lower incidence (Table 1). Indeed, these results corroborate early reports that showed limited lignin degradation in the ruminal environment, mostly because of its natural microaerobic condition [93]. Five enzyme families essential for degradation or modification of lignin were detected in the rumen (i.e., AA6, AA5, AA4, AA7, and AA3). Phylogenetic analysis showed that species of bacteria belonging to genera Prevotella, Bacteroides, Clostridium, Fibrobacter, and Ruminococcus are key contributors of CAZymes inhabiting the cow's rumen [75].

Beloqui et al. (2006) reported RL5, a gene coding for a polyphenol oxidase with laccase activity from a bovine rumen metagenomic library. Characterization of the recombinant laccase produced in Escherichia coli revealed its ability to oxidize different substrates such as syringaldazine, 2,6-dimethoxyphenol, veratryl alcohol, guaiacol, tetramethylbenzidine, 4-methoxybenzyl alcohol, 2,2'-azino-bis(3-ethylbenzothiazoline-6-sulfonic acid) (ABTS), and phenol red, over a wide $\mathrm{pH}$ range. Phylogenetic analysis assigned this laccase sequence to the genus Bacteroides [94].

Similarly, Ufarté et al. (2018) found in the bovine rumen microbiome producers of enzymes able to oxidize phenolic compounds such as ABTS (2,2'-azino-bis(3-ethylbenzothiazoline6-sulfonic acid)), syringaldehyde, 1-hydroxybenzotriazole, acetosyringone, and 2,2'-azinobis without the addition of mediators such as copper or manganese, presenting activity in a wide range of temperatures $\left(45\right.$ to $60^{\circ} \mathrm{C}$ ) and $\mathrm{pH}$ (4.5 up to 5.5) [95].

Work focusing on the rumen microbiome of a more exotic ungulate, the camel, identified bacteria associated with lignin degradation. These bacteria were able to produce enzymes with auxiliary activities categorized into four families (AA3, AA4, AA6, and AA7), of which a 1,4-benzoquinone reductase belonging to AA6 accounted for $>90 \%$ of the 1319 sequences. The auxiliary activity enzyme (AA6) was also abundant in the cow rumen biogas reactor microbiome [76]. Still, regarding the camel's rumen microbiome, Firmicutes species contributed with $48 \%$ of the AAs found, Bacteroidetes species with $35 \%$, Spirochaetaes with $8 \%$, and Fibrobacteres and Proteobacteria species contributed with $4 \%$ [76].

Families of AAs represented $0.13 \%$ of the total number of CAZyme families found in the fecal samples of Asian elephants (Table 1). Among these, AA4 was the most abundant $(50 \%)$ followed by AA6 members (20\%) [77]. These numbers showed a different prevalence in comparison to the biogas fermenter, camel, and cow rumen where AA6 was the most abundant family $[75,76]$.

\subsection{Culture Enrichment}

Culture enrichment using lignin as the main carbon source facilitates the identification of key microorganisms for its deconstruction and biotransformation. For example, the taxonomic and functional analysis of bacterial consortia derived from soil and chicken feces enriched in wood chips or filter paper, and subcultured in alkali lignin containing medium showed that Pseudomonas has a central role in the deconstruction of aromatic compounds. In addition to their high abundance in the consortia, they also had most of the genes involved in the ortho-cleavage and degradation pathways of benzoate and catechol. Other genera such as Klebsiella, Variovorax, Leclercia, and Enterobacter were also associated with lignin degradation [96].

Moraes et al. (2018) [97], used 16S rRNA gene sequencing and shotgun metagenomics to characterize a ligninolytic consortium obtained by cultivation of a sample of sugarcane soil in a medium containing low molecular weight soluble lignin as a carbon source. The authors reported an increase in the abundance of the families Alcaligenaceae and Micrococcaceae and reported for the first time the involvement of the genus Pseudomaniobacter in the degradation of aromatic compounds derived from lignin. Functional analysis of this 
consortium revealed the presence of different families of auxiliary activities (AA3, AA4, $\mathrm{AA6}$, and AA7) and genes of the main pathways related to the degradation of aromatic compounds such as benzoate and phthalate (Table 2).

Table 2. Auxiliary activity families (AAs) and metabolic pathways of aromatic compounds consumption present in different bacterial consortium identified in metagenomic studies.

\begin{tabular}{|c|c|c|c|c|}
\hline $\begin{array}{l}\text { Consortium Source and Bacteria } \\
\text { with Ligninolytic Potential }\end{array}$ & Substrate & $\begin{array}{c}\text { AA } \\
\text { Families }\end{array}$ & $\begin{array}{l}\text { Pathways of Consuming } \\
\text { Aromatic Compounds }\end{array}$ & References \\
\hline $\begin{array}{l}\text { Enrichment from } \\
\text { chicken feces and } \\
\text { soil (Pseudomonas, } \\
\text { Klebsiella, Variovorax, Leclercia, and } \\
\text { Enterobacter) }\end{array}$ & Alkali lignin & - & $\begin{array}{l}\text { Catechol ortho- } \\
\text { cleavage and } \\
\text { benzoate degradation } \\
\text { pathways }\end{array}$ & [96] \\
\hline $\begin{array}{l}\text { Enrichment from } \\
\text { sugarcane plantation } \\
\text { soil (Proteobacteria, } \\
\text { Actinobacteria, } \\
\text { Firmicutes, } \\
\text { Alcaligenaceae, and } \\
\text { Micrococcaceae) }\end{array}$ & $\begin{array}{l}\text { Low-molecular- } \\
\text { weight (LW) } \\
\text { lignin }\end{array}$ & $\begin{array}{l}\text { AA2, AA3, } \\
\text { AA4, AA6, and } \\
\text { AA7 }\end{array}$ & $\begin{array}{l}\text { Benzoate degradation } \\
\text { to catechol, catechol } \\
\text { ortho-cleavage, } \\
\text { catechol meta- } \\
\text { cleavage, and } \\
\text { phthalate degradation }\end{array}$ & [97] \\
\hline $\begin{array}{l}\text { Enrichment from soil } \\
\text { (Brevundimonas, } \\
\text { Caulobacter, } \\
\text { Pseudomonas, } \\
\text { Citrobacter, and } \\
\text { Aeromonas) }\end{array}$ & $\begin{array}{l}\text { Wheat straw } \\
\text { switchgrass and } \\
\text { corn stover }\end{array}$ & $\begin{array}{l}\mathrm{AA} 2, \mathrm{AA} 4 \\
\mathrm{AA} 6, \text { and AA7 }\end{array}$ & - & [98] \\
\hline $\begin{array}{l}\text { Enrichment from } \\
\text { compost ecosystems } \\
\text { (Proteobacteria and } \\
\text { Firmicutes) }\end{array}$ & Corn stover & $\begin{array}{l}\mathrm{AA} 2, \mathrm{AA} 3 \\
\mathrm{AA} 4, \mathrm{AA} 6 \text { and } \\
\mathrm{AA} 7\end{array}$ & - & [99] \\
\hline $\begin{array}{l}\text { Enrichment from } \\
\text { compost ecosystems } \\
\text { (Symbiobacterium } \\
\text { thermophilum, T. } \\
\text { curvata, } \\
\text { Mycobacterium } \\
\text { xenopi, } \\
\text { Amycolicicoccus } \\
\text { subflavus and } \\
\text { Mycobacterium } \\
\text { thermoresistibile) }\end{array}$ & Rice straw & AA2 & - & [100] \\
\hline $\begin{array}{l}\text { Enrichment from } \\
\text { compost ecosystems } \\
\text { (Sphaerobacter, } \\
\text { Hyphomicrobium, } \\
\text { Thermus } \\
\text { thermophilus, } \\
\text { Sphaerobacter, } \\
\text { Gemmatimonadetes, } \\
\text { Paenibacillus) }\end{array}$ & Switchgrass & AA2 & $\begin{array}{l}\text { Ortho-cleavage of } \\
\text { protocatechuate and } \\
4- \\
\text { hydroxyphenylacetate } \\
\text { degradation }\end{array}$ & [101] \\
\hline $\begin{array}{l}\text { Enriched from } \\
\text { compost ecosystems } \\
\text { (Thermobacillus } \\
\text { species, Bacillus) }\end{array}$ & CMC & $\begin{array}{l}\text { AA1, AA2, } \\
\text { AA4, AA6, and } \\
\text { AA7 }\end{array}$ & - & [102] \\
\hline
\end{tabular}

Three microbial consortia started from soils supplemented with wheat straw (WS1-M), switchgrass (SG-M), and corn stover (CS-M) were described as presenting a set of genes belonging to auxiliary activities families. AA6 family members were the most abundant, followed by members of the AA2, AA7, and AA4 families. The highest rate of lignin 
deconstruction, approximately 59\%, was recorded for the SG-M consortium, which had a high abundance of the genera Brevundimonas, Caulobacter, Pseudomonas, Citrobacter, and Aeromonas [98].

In a microbial consortium generated from the cultivation of compost samples in media containing corn stover as the carbon source, 22 genes encoding AAs were assigned to Firmicutes and Proteobacteria. Only four genes encoding members of the AA2 family have been attributed to Escherichia and Klebsiella from the Proteobacteria phylum [99]. In contrast, a different straw-adapted compost microbial consortium was enriched for AA2 family genes, distributed among Actinobacteria species, a novelty, since these members were not previously recognized as active on lignin. Among the species identified were Thermomonospora curvata, Mycobacterium xenopi, Amycolicicoccus subflavus, and Mycobacterium thermoresistibile [100].

In a thermophilic consortium adapted to degrade switchgrass through multiple passages at $60{ }^{\circ} \mathrm{C}$, several putative genes belonging to the AA1 family were assigned to Thermus thermophilus, Sphaerobacter, Gemmatimonadetes spp., and Paenibacillus spp. Additionally, genes for families of glutathione S-transferases have also been found in the genus of Hyphomicrobium. This family of enzymes contains members that are involved in the cleavage of beta-aryl linked lignin dimers [101]. In another thermophilic bacterial consortium enriched with carboxymethylcellulose (CMC), six bacterial genomes were partially reconstructed and named as BZ1, BZ2, BZ3, BZ4, BZ5, and BZ6. Taxonomic and phylogenetic analysis suggest that three of the six reconstructed genomes belong to new bacteria: Thermobacillus (BZ1); a member of a new genus in the family Paenibacillaceae (BZ3), similar to Paenibacillus and Cohnella; and a member of a new deep-branching family in the Clostridia (BZ6) class. Six families of auxiliary activities related to the degradation of lignin (AA1, AA2, AA4, AA6, and AA7) were found in the six reconstructed genomes [102].

\subsection{Metatranscriptomics and Metaproteomics Approaches}

\subsubsection{Metatranscriptomics}

Metatranscriptomics is the study of the rRNA and mRNA of a microbial community, which provides information on the active functional profile through the evaluation of gene expression (Figure 5) [103]. In contrast to metagenomics, which describes the composition, function, and relative abundance of different members of a microbial community, metatranscriptomics provides insight into the metabolically active part of the community. Therefore, metatranscriptomic analysis is restricted to transcribed genes, and the non-transcribed portions of the genome that are frequent in metagenomic data are not present [104]. However, technical limitations for effective RNA recovery, low quantities of bacterial mRNA in samples, and the short lifetime of mRNA can restrict the application of this approach. The transcriptional profile of auxiliary activity genes involved in lignin degradation is summarized in Table 3.

Table 3. Families of auxiliary activities (AAs) present in different bacterial communities, as researched from metaomics studies.

\begin{tabular}{lllr}
\hline Sample & Omics Techniques Applied & AAs Families & References \\
\hline Compost ecosystems & Metatranscriptomics & AA2, AA3, AA4, AA6, and AA7 & {$[105]$} \\
Soil microbiota & Metatranscriptomics & AA2 and AA6 & {$[106]$} \\
Forest soil & Metatranscriptomics & AA1 and AA3 & {$[69]$} \\
Termite gut & Metatranscriptomics & AA2, AA4, and AA6 & {$[107]$} \\
Termite gut & Metatranscriptomics & AA4 and AA6 & {$[108]$} \\
Bacterial consortium & Metaproteomics & AA2 and AA7 & {$[109]$} \\
Bacterial consortium & Metaproteomics & AA2 & {$[99]$} \\
\hline
\end{tabular}



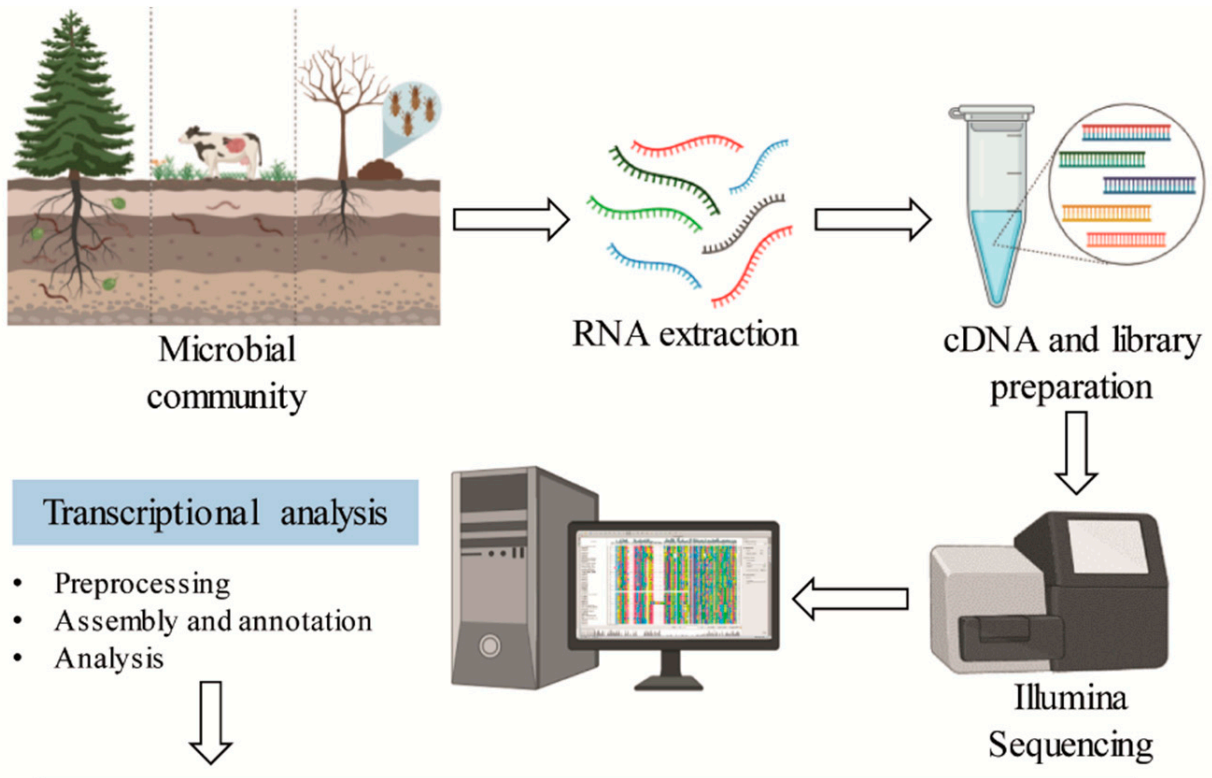

cDNA and library preparation

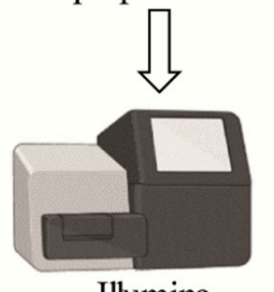

Illumina
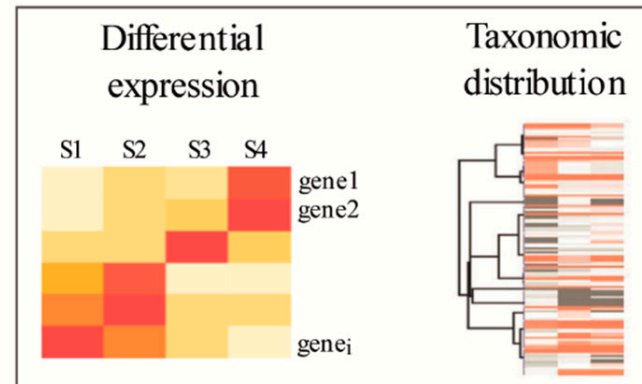

Sequencing

Figure 5. General scheme for functional and genetic profiling of oxidative enzymes exploiting metatranscriptomic sequence data.

Active metabolic pathways of the microbial community in a thermophilic composting operation in the São Paulo Zoo Park have been unraveled through metatranscriptomics [105]. Lignin deconstruction occurred sequentially and synergistically by the action of ligninases that reached peak abundance at the end of the composting process. The majority of ligninolytic enzymes belonging to the classes AA2 (7-28\% of all AAs) and AA6 (32-66\%), followed by moderate amounts of AA3, 4, and 7, were found in all samples. Members of Clostridiales, Bacillales, and Actinomycetales were implicated as the major compost-degrading microbes, particularly in the thermophilic and mature stages of the composting process [105].

The temporal expression dynamics of a set of plant biomass-degrading enzymes by a bacterial consortium growing on sugarcane bagasse was studied. Here, Jiménez et al. (2018) described the importance of the expression of auxiliary activities AA2 and AA6. The highest expression levels of transcripts encoding AA2 and AA6 members of families derived from Paenibacillus and Brevundimonas were observed at early stages (at $12 \mathrm{~h}$ ) of the consortium's growth. According to the authors, this could be related to cell protection against oxidative damage and electron transfer. Finally, the expression of catalase-peroxidases (AA2) was carried out by Chryseobacterium and Brevundimonas at the final stages (192 h), suggesting that the degradation of lignin occurred in the final stages of growth of the consortium [106].

Moreover, Žifčáková et al. (2017) investigated the glycoside hydrolases and auxiliary enzyme contribution of fungi and bacteria in two different stations on top forest soil. A high diversity of transcription in families of AA3 (mixed activities in lignocellulose) and AA1 (laccases) was reported. Concerning CAZymes functional groups, those destined for cellulose were more transcribed, followed by those that act on lignin [69]. 
Tokuda et al. (2018) identified transcripts encoding three families of auxiliary activities belonging to AA6, AA4, and AA2 involved in bioconversion of phenolic compounds in the hindgut compartment from termites (Nasutitermes takasagoensis) [107]. Additionally, Marynowska et al. (2017), studied the lignocellulolytic potential of the higher termite gut prokaryotes. They reported transcripts encoding enzymes such as AA4 (vanillyl alcohol oxidase), and AA6 families (1,4-benzoquinone reductase) [108].

\subsubsection{Metaproteomics}

Metaproteomics allows the assessment of the complete protein content of an environmental microbiota (Figure 6). The main challenges of metaproteomics include sample complexity, low peptide identification, and lack of complete databases [110,111]. Although there are still only a few studies that have reported the presence of enzymes related to lignin degradation, the use of this approach in lignocellulolytic bacterial communities has demonstrated the presence of auxiliary activities involved in the deconstruction of lignin (Table 3).

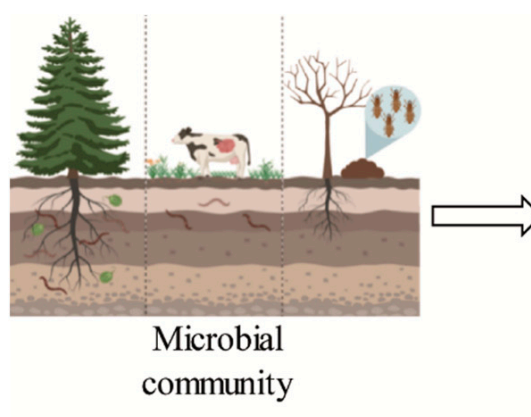

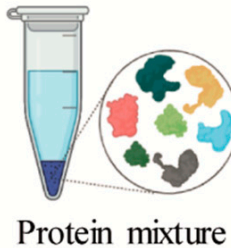

Protein mixture

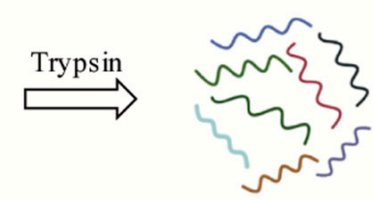

Digested peptides
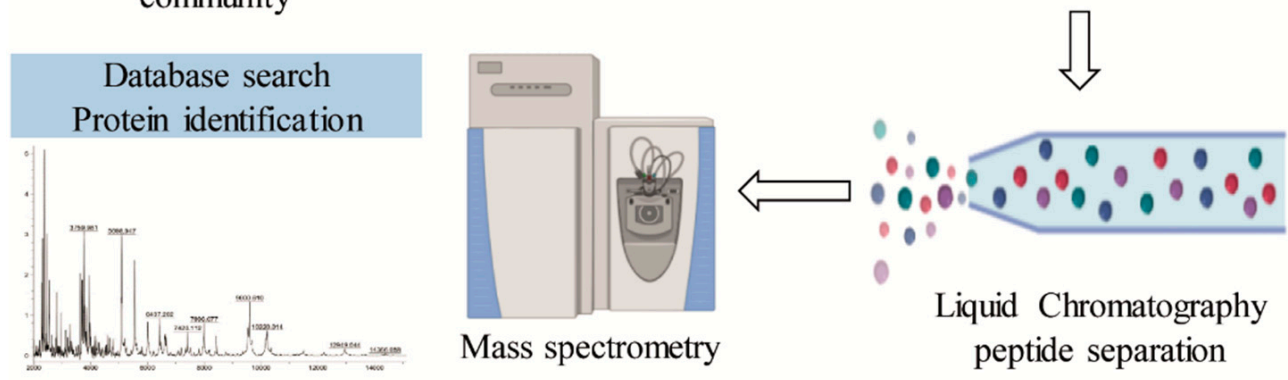

Figure 6. General scheme of the metaproteomic analysis for the identification of lignin-degrading enzymes from different bacterial communities.

For example, the analysis of the bacterial consortium secretome adapted to using rice straw as a carbon source showed the presence of 16 domains of auxiliary activities belonging to three families (AA2, AA7, and AA10). Interestingly, in addition to singledomain CAZymes, other proteins with multiple domains have been identified, for example, ligninolytic proteins containing three distinct AA2 domains. The main groups responsible for the deconstruction of this biomass belonged to the phyla Proteobacteria and Bacteroidetes [109].

In contrast, for another consortium adapted to corn stover, only one AA2 protein (catalase/peroxidase) from Escherichia coli was considered potentially involved in the degradation of lignin [99]. Likewise, in another bacterial consortium adapted for using switchgrass as a carbon source, only a putative laccase assigned to the Gemmatimonadetes was identified [101].

\section{Application of Lignin-Active Enzymes}

Nowadays, with a growing interest in green processes, microbial enzymes are the major biological players sought after for industrial applications. Lignin-active enzymes are prospected for many applications such as decontamination of industrial dyes [112], general 
delignification for diminishing lignocellulose recalcitrance [16], and the production of aromatic compounds of industrial relevance [8]. As previously discussed, enzymes produced by filamentous fungi are the prime source for industrial applications, however, bacteria can produce enzymes with interesting kinetic parameters that should be further exploited.

The major challenge in using enzymes produced by bacteria instead of those secreted by classic filamentous fungi such as Trichoderma sp. is related to enzyme production levels. Filamentous fungi that are prospected for enzyme production are naturally specialized in secreting enzymes with activity against lignin and holocellulose $[113,114]$. The utilization of similar enzymes obtained from bacteria requires recombinant production of these enzymes in host cells suitable to industrial conditions. In this regard, heterologous expression and a direct evolution approach to improve catalytic activity, enhance expression levels, and improve laccase stability have been pursued to convert bacterial laccases into highly efficient and commercially valuable biocatalysts [13].

Bio-delignification by AA1 family (laccases) provides a clean and efficient treatment method of lignocellulose without damaging the cellulose, which is important for commercial bioethanol production. Researchers have shown that laccases can work more efficiently in combination with hemicellulases for lignocellulose saccharification. However, Rocha-Martín et al. [115], reported that supplementation of laccase in enzymatic hydrolysis showed contradictory results, depending on pretreatment type and biomass used. The addition of laccase to softwood hydrolysis resulted in high glucose yield, while a negative effect was obtained for hardwood hydrolysis.

AA1 families have successfully reported effectiveness for kraft pulps and biobleaching. Arias et al. (2003) showed that the biobleaching of eucalyptus kraft pulps by lacasse (AA1_1 family) from Streptomyces cyaneus CECT 3335 using ABTS as a mediator resulted in the significant decrease in the kappa number up to $2.3 \mathrm{U}$ and increased pulp brightness. An alkaline and halotolerant bacterial laccase (SilA) produced by Streptomyces ipomoea CECT 3341 was also used to enhance the conventional chemical bleaching process of an industrial eucalyptus kraft pulp $[47,116]$.

Lignin deconstruction and detoxification of aromatic compounds by bacterial enzymes is a widely investigated topic. However, details on bacterial uptake and metabolization of the compounds released during lignin breakdown is still a relatively less investigated topic. Recent studies are not only focusing on how the bacterial enzymatic machinery works in lignin deconstruction, but also on investigating how these compounds are metabolized. Although the intention of this review is not to describe the detailed pathways, it is clear that the bacterial metabolism of lignin can generate interesting biotechnological products such as bioplastics, vanillin, and lipids that can be further transformed into biofuels [43].

\section{Conclusions and Future Perspectives}

The use of metagenomic approaches to study lignocellulosic microbial communities present in different environments has revealed the ligninolytic potential of several bacteria including new non-cultivable clades such as Caulobacteraceae, Solirubrobacterales, and Cystobacteraceae. It has also allowed access to a set of potential bacterial genes for auxiliary activities, belonging mainly to families AA2, AA3, AA4, AA5, AA6, and AA7, which are involved in the degradation of lignin and other components of the plant cell wall. One limitation of metagenomics is that it does not provide information about active microbial communities. This is why complementary approaches such as metatranscriptomics and metaproteomics need to be used. Studies using these two latter approaches have shown the presence of auxiliary bacterial activities related to lignin degradation (Table 3). To date, there are still few studies related to bacterial degradation of lignin using omics approaches, and these mainly use metaproteomics. Future work aimed at the bacterial degradation of lignin needs to take advantage of the integrative use of the three omics approaches. Together, these will likely generate a more comprehensive understanding of microbial degradation and/or modification of lignin. 
Author Contributions: J.P.S.: writing—original draft preparation. A.R.P.T.: writing—original draft preparation. P.R.V.H.: writing-original draft preparation. B.F.Q.: writing-review, and editing. E.F.N.: writing-review and editing, funding acquisition. All authors have read and agreed to the published version of the manuscript.

Funding: This research was funded by grants from EMBRAPA, Universidade de Brasília, CAPES, and CNPq. J.P.S. and P.R.V.H. are recipients of a CAPES doctoral scholarship. E.F.N. and B.F.Q. are recipients of a $\mathrm{CNPq}$ research fellowship.

Conflicts of Interest: The authors declare no conflict of interest.

\section{References}

1. De Bhowmick, G.; Sarmah, A.K.; Sen, R. Lignocellulosic biorefifinery as a model for sustainable development of biofuels and value added products. Bioresour. Technol. 2018, 247, 1144-1154. [CrossRef] [PubMed]

2. Tursi, A. A review on biomass: Importance, chemistry, classification, and conversion. Biofuel Res. J. 2019, 6, 962-979. [CrossRef]

3. Barapatre, A.; Jha, H. Degradation of alkali lignin by two ascomycetes and free radical scavenging activity of the products. Biocatal. Biotransform. 2017, 35, 269-286. [CrossRef]

4. Bugg, T.D.H.; Ahmad, M.; Hardiman, E.M.; Rahmanpour, R. Pathways for degradation of lignin in bacteria and fungi. Nat. Prod. Rep. 2011, 28, 1883-1896. [CrossRef] [PubMed]

5. Lee, S.; Kang, M.; Bae, J.H.; Sohn, J.H.; Sung, B.H. Bacterial Valorization of Lignin: Strains, Enzymes, Conversion Pathways, Biosensors, and Perspectives. Front. Bioeng. Biotechnol. 2019, 7, 209. [CrossRef]

6. Kim, K.H.; Kim, C.S. Recent efforts to prevent undesirable reactions from fractionation to depolymerization of lignin: Toward maximizing the value from lignin. Front. Energy Res. 2018, 6, 92. [CrossRef]

7. $\quad \mathrm{Pu}, \mathrm{Y}$.; Hu, F.; Huang, F.; Davison, B.H.; Ragauskas, A.J. Assessing the molecular structure basis for biomass recalcitrance during dilute acid and hydrothermal pretreatments. Biotechnol. Biofuels 2013, 6, 15. [CrossRef]

8. Schoenherr, S.; Ebrahimi, M.; Czermak, P. Lignin Degradation Processes and the Purification of Valuable Products. In Lignin: Trends and Applications; Books on Demand: Norderstedt, Germany, 2018.

9. Ravi, K.; García-Hidalgo, J.; Gorwa-Grauslund, M.F.; Lidén, G. Conversion of lignin model compounds by Pseudomonas putida KT2440 and isolates from compost. Appl. Microbiol. Biotechnol. 2017, 101, 5059-5070. [CrossRef]

10. Dessbesell, L.; Paleologou, M.; Leitch, M.; Pulkki, R.; Xu, C. (Charles) Global lignin supply overview and kraft lignin potential as an alternative for petroleum-based polymers. Renew. Sustain. Energy Rev. 2020, 123, 109768. [CrossRef]

11. Dashtban, M.; Schraft, H.; Syed, T.A.; Qin, W. Fungal biodegradation and enzymatic modification of lignin. Int. J. Biochem. Mol. Biol. 2010, 1, 36-50.

12. Zhu, D.; Zhang, P.; Xie, C.; Zhang, W.; Sun, J.; Qian, W.J.; Yang, B. Biodegradation of alkaline lignin by Bacillus ligniniphilus L1. Biotechnol. Biofuels 2017, 10, 44. [CrossRef] [PubMed]

13. Guan, Z.B.; Luo, Q.; Wang, H.R.; Chen, Y.; Liao, X.R. Bacterial laccases: Promising biological green tools for industrial applications. Cell. Mol. Life Sci. 2018, 75, 3569-3592. [CrossRef] [PubMed]

14. Riyadi, F.A.; Tahir, A.A.; Yusof, N.; Sabri, N.S.A.; Noor, M.J.M.M.; Akhir, F.N.M.D.; Othman, N.; Zakaria, Z.; Hara, H. Enzymatic and genetic characterization of lignin depolymerization by Streptomyces sp. S6 isolated from a tropical environment. Sci. Rep. 2020, 10, 7813-7819. [CrossRef] [PubMed]

15. Xu, Z.; Lei, P.; Zhai, R.; Wen, Z.; Jin, M. Recent advances in lignin valorization with bacterial cultures: Microorganisms, metabolic pathways, and bio-products. Biotechnol. Biofuels 2019, 12, 32. [CrossRef] [PubMed]

16. Shi, Y.; Chai, L.; Tang, C.; Yang, Z.; Zheng, Y.; Chen, Y.; Jing, Q. Biochemical investigation of kraft lignin degradation by pandoraea sp. B-6 isolated from bamboo slips. Bioprocess Biosyst. Eng. 2013, 36, 1957-1965. [CrossRef] [PubMed]

17. Scully, E.D.; Geib, S.M.; Hoover, K.; Tien, M.; Tringe, S.G.; Barry, K.W.; Glavina del Rio, T.; Chovatia, M.; Herr, J.R.; Carlson, J.E. Metagenomic Profiling Reveals Lignocellulose Degrading System in a Microbial Community Associated with a Wood-Feeding Beetle. PLoS ONE 2013, 8, e73827. [CrossRef]

18. Oh, H.N.; Park, D.; Seong, H.J.; Kim, D.; Sul, W.J. Antarctic tundra soil metagenome as useful natural resources of cold-active lignocelluolytic enzymes. J. Microbiol. 2019, 57, 865-873. [CrossRef]

19. Ralph, J. Hydroxycinnamates in lignification. Phytochem. Rev. 2010, 9, 65-83. [CrossRef]

20. Ferreira, S.S.; Simões, M.S.; Carvalho, G.G.; de Lima, L.G.A.; de Almeida Svartman, R.M.; Cesarino, I. The lignin toolbox of the model grass Setaria viridis. Plant Mol. Biol. 2019, 101, 235-255. [CrossRef]

21. Cesarino, I.; Araújo, P.; Domingues, A.P.; Mazzafera, P. An overview of lignin metabolism and its effect on biomass recalcitrance. Rev. Bras. Bot. 2012, 35, 303-311. [CrossRef]

22. Ragauskas, A.J.; Beckham, G.T.; Biddy, M.J.; Chandra, R.; Chen, F.; Davis, M.F.; Davison, B.H.; Dixon, R.A.; Gilna, P.; Keller, M.; et al. Lignin valorization: Improving lignin processing in the biorefinery. Science 2014, 344, 1246843. [CrossRef] [PubMed]

23. Li, C.; Zhao, X.; Wang, A.; Huber, G.W.; Zhang, T. Catalytic Transformation of Lignin for the Production of Chemicals and Fuels. Chem. Rev. 2015, 115, 11559-11624. [CrossRef] [PubMed]

24. Boerjan, W.; Ralph, J.; Baucher, M. Lignin Biosynthesis. Annu. Rev. Plant Biol. 2003, 54, 519-546. [CrossRef] 
25. Lourenço, A.; Pereira, H. Compositional Variability of Lignin in Biomass. In Lignin: Trends and Applications; Books on Demand: Norderstedt, Germany, 2018.

26. Molinari, H.B.C.; Pellny, T.K.; Freeman, J.; Shewry, P.R.; Mitchell, R.A.C. Grass cell wall feruloylation: Distribution of bound ferulate and candidate gene expression in Brachypodium distachyon. Front. Plant Sci. 2013, 4, 50. [CrossRef] [PubMed]

27. Ponnusamy, V.K.; Nguyen, D.D.; Dharmaraja, J.; Shobana, S.; Banu, J.R.; Saratale, R.G.; Chang, S.W.; Kumar, G. A review on lignin structure, pretreatments, fermentation reactions and biorefinery potential. Bioresour. Technol. 2019, 271, 462-472. [CrossRef] [PubMed]

28. Lu, Y.; Lu, Y.C.; Hu, H.Q.; Xie, F.J.; Wei, X.Y.; Fan, X. Structural characterization of lignin and its degradation products with spectroscopic methods. J. Spectrosc. 2017, 2017, 8951658. [CrossRef]

29. Giummarella, N.; Pu, Y.; Ragauskas, A.J.; Lawoko, M. A critical review on the analysis of lignin carbohydrate bonds. Green Chem. 2019, 21, 1573-1595. [CrossRef]

30. Yoo, C.G.; Meng, X.; Pu, Y.; Ragauskas, A.J. The critical role of lignin in lignocellulosic biomass conversion and recent pretreatment strategies: A comprehensive review. Bioresour. Technol. 2020, 301, 122784. [CrossRef]

31. Vogel, J. Unique aspects of the grass cell wall. Curr. Opin. Plant Biol. 2008, 11, 301-307. [CrossRef]

32. Amin, F.R.; Khalid, H.; Zhang, H.; Rahman, S.; Zhang, R.; Liu, G.; Chen, C. Pretreatment methods of lignocellulosic biomass for anaerobic digestion. AMB Express 2017, 7, 72. [CrossRef]

33. Jedrzejczyk, M.; Soszka, E.; Czapnik, M.; Ruppert, A.M.; Grams, J. Physical and chemical pretreatment of lignocellulosic biomass. In Second and Third Generation of Feedstocks; Basile, A., Dalena, F., Eds.; Elsevier: Amsterdam, The Netherlands, 2019 ; pp. 143-196. ISBN 9780128151624.

34. Jönsson, L.J.; Martín, C. Pretreatment of lignocellulose: Formation of inhibitory by-products and strategies for minimizing their effects. Bioresour. Technol. 2015, 199, 103-112. [CrossRef] [PubMed]

35. Gil-Chávez, J.; Gurikov, P.; Hu, X.; Meyer, R.; Reynolds, W.; Smirnova, I. Application of novel and technical lignins in food and pharmaceutical industries: Structure-function relationship and current challenges. Biomass Convers. Biorefinery 2019. [CrossRef]

36. Li, T.; Takkellapati, S. The current and emerging sources of technical lignins and their applications. Biofuels Bioprod. Biorefining 2018, 12, 756-787. [CrossRef]

37. Eraghi Kazzaz, A.; Fatehi, P. Technical lignin and its potential modification routes: A mini-review. Ind. Crop. Prod. 2020, 154, 112732. [CrossRef]

38. Kumar, A.K.; Sharma, S. Recent updates on different methods of pretreatment of lignocellulosic feedstocks: A review. Bioresour. Bioprocess. 2017, 4, 7. [CrossRef]

39. Baruah, J.; Nath, B.K.; Sharma, R.; Kumar, S.; Deka, R.C.; Baruah, D.C.; Kalita, E. Recent Trends in the Pretreatment of Lignocellulosic Biomass for Value-Added Products. Front. Chem. 2018, 6, 1-19. [CrossRef]

40. Li, M.; Pu, Y.; Ragauskas, A.J. Current understanding of the correlation of lignin structure with biomass recalcitrance. Front. Chem. 2016, 4, 45. [CrossRef] [PubMed]

41. Angeler, D.G.; Fried-Petersen, H.; Allen, C.R.; Garmestani, A.; Chuang, W.; Donovan, V.M.; Eason, T.; Roberts, C.P.; Wonkka, C.L.; Survey, G.; et al. The current and emerging sources of technical lignins and their applications. Adv. Ecol. Res. 2019, 60, 1-24. [CrossRef] [PubMed]

42. Lombard, V.; Ramulu, H.G.; Drula, E.; Coutinho, P.M.; Henrissat, B. The carbohydrate-active enzymes database (CAZy) in 2013. Nucleic Acids Res. 2014, 42, 490-495. [CrossRef]

43. Xu, R.; Zhang, K.; Liu, P.; Han, H.; Zhao, S.; Kakade, A.; Khan, A.; Du, D.; Li, X. Lignin depolymerization and utilization by bacteria. Bioresour. Technol. 2018, 269, 557-566. [CrossRef]

44. Crawford, D.L.; Crawford, R.L. Microbial degradation of lignocellulose: The lignin component. Appl. Environ. Microbiol. 1976, 31, 714-717. [CrossRef] [PubMed]

45. Claus, H. Laccases: Structure, reactions, distribution. Micron 2004, 35, 93-96. [CrossRef] [PubMed]

46. de Gonzalo, G.; Colpa, D.I.; Habib, M.H.M.; Fraaije, M.W. Bacterial enzymes involved in lignin degradation. J. Biotechnol. 2016, 236, 110-119. [CrossRef] [PubMed]

47. Eugenio, M.E.; HErnández, M.; Moya, R.; Sampedro, R.M.; Villar, J.C.; Arias, E. Evaluation of a new laccase produced by Streptomyces ipo- moea on biobleaching and ageing of kraft pilps. Bioresources 2011, 6, 3231-3241.

48. Givaudan, A.; Effosse, A.; Faure, D.; Potier, P.; Bouillant, M.L.; Bally, R. Polyphenol oxidase in Azospirillum lipoferum isolated from rice rhizosphere: Evidence for laccase activity in non-motile strains of Azospirillum lipoferum. FEMS Microbiol. Lett. 1993, 108, 205-210. [CrossRef]

49. Rezaei, S.; Shahverdi, A.R.; Faramarzi, M.A. Isolation, one-step affinity purification, and characterization of a polyextremotolerant laccase from the halophilic bacterium Aquisalibacillus elongatus and its application in the delignification of sugar beet pulp. Bioresour. Technol. 2017, 230, 67-75. [CrossRef]

50. Chen, C.; Huang, Y.; Wei, C.; Meng, M.; Liu, W.; Yang, C. Properties of the newly isolated extracellular thermo-alkali-stable laccase from thermophilic actinomycetes, Thermobifida fusca and its application in dye intermediates oxidation. AMB Express 2013, 3, 49. [CrossRef]

51. de Oliveira, P.L.; Duarte, M.C.T.; Ponezi, A.N.; Durrant, L.R. Purification and partial characterization of manganese peroxidase from Bacillus pumilus and Paenibacillus sp. Braz. J. Microbiol. 2009, 40, 818-826. [CrossRef] 
52. Anderson, C.R.; Johnson, H.A.; Caputo, N.; Davis, R.E.; Torpey, J.W.; Tebo, B.M. Mn(II) oxidation is catalyzed by heme peroxidases in "Aurantimonas manganoxydans" strain SI85-9A1 and Erythrobacter sp. strain SD-21. Appl. Environ. Microbiol. 2009, 75, 4130-4138. [CrossRef]

53. Nayanashree, G.; Thippeswamy, B. Biodegradation of Natural Rubber by Laccase and Manganese Peroxidase Enzyme of Bacillus subtilis. Environ. Process. 2015, 2, 761-772. [CrossRef]

54. Kharayat, Y.; Thakur, I.S. Isolation of bacterial strain from sediment core of Pulp and Paper Mill industries for production and purification of lignin peroxidase (LiP) enzyme. Bioremediat. J. 2012, 16, 125-130. [CrossRef]

55. Gomare, S.S.; Jadhav, J.P.; Govindwar, S.P. Degradation of sulfonated azo dyes by the purified lignin peroxidase from Brevibacillus laterosporus MTCC 2298. Biotechnol. Bioprocess Eng. 2008, 13, 136-143. [CrossRef]

56. Yee, D.C.; Wood, T.K. 2,4-Dichlorophenol Degradation Using Streptomyces visidosporus T7A Lignin Peroxidase. Biotechnol. Prog. 1997, 13, 53-59. [CrossRef]

57. Jeon, J.H.; Han, Y.J.; Kang, T.G.; Kim, E.S.; Hong, S.K.; Jeong, B.C. Purification and characterization of 2,4-dichlorophenol oxidizing peroxidase from Streptomyces sp. AD001. J. Microbiol. Biotechnol. 2002, 12, 972-978.

58. Sonoki, T.; Iimura, Y.; Masai, E.; Kajita, S.; Katayama, Y. Specific degradation of $\beta$-aryl ether linkage in synthetic lignin (dehydrogenative polymerizate) by bacterial enzymes of Sphingomonas paucimobilis SYK-6 produced in recombinant Escherichia coli. J. Wood Sci. 2002, 48, 429-433. [CrossRef]

59. Pereira, J.H.; Heins, R.A.; Gall, D.L.; McAndrew, R.P.; Deng, K.; Holland, K.C.; Donohue, T.J.; Noguera, D.R.; Simmons, B.A.; Sale, K.L.; et al. Structural and biochemical characterization of the early and late enzymes in the lignin $\beta$-aryl ether cleavage pathway from sphingobium sp. SYK-6. J. Biol. Chem. 2016, 291, 10228-10238. [CrossRef] [PubMed]

60. Schmeisser, C.; Steele, H.; Streit, W.R. Metagenomics, biotechnology with non-culturable microbes. Appl. Microbiol. Biotechnol. 2007, 75, 955-962. [CrossRef] [PubMed]

61. Batista-García, R.A.; del Rayo Sánchez-Carbente, M.; Talia, P.; Jackson, S.A.; O’Leary, N.D.; Dobson, A.D.W.; Folch-Mallol, J.L. From lignocellulosic metagenomes to lignocellulolytic genes: Trends, challenges and future prospects. Biofuels, Bioprod. Biorefining 2016, 10, 864-882. [CrossRef]

62. Quince, C.; Walker, A.W.; Simpson, J.T.; Loman, N.J.; Segata, N. Supplement-study design Shotgun metagenomics, from sampling to analysis. Nat. Biotechnol. 2017, 35, 833-844. [CrossRef] [PubMed]

63. Breitwieser, F.P.; Lu, J.; Salzberg, S.L. A review of methods and databases for metagenomic classification and assembly. Brief. Bioinform. 2018, 20, 1125-1139. [CrossRef] [PubMed]

64. Bai, X.; Lu, S.; Yang, J.; Jin, D.; Pu, J.; Díaz Moyá, S.; Xiong, Y.; Rossello-Mora, R.; Xu, J. Precise Fecal Microbiome of the Herbivorous Tibetan Antelope Inhabiting High-Altitude Alpine Plateau. Front. Microbiol. 2018, 9, 2321. [CrossRef]

65. Simon, C.; Daniel, R. Metagenomic analyses: Past and future trends. Appl. Environ. Microbiol. 2011, 77, 1153-1161. [CrossRef] [PubMed]

66. Lam, K.N.; Cheng, J.; Engel, K.; Neufeld, J.D.; Charles, T.C. Current and future resources for functional metagenomics. Front. Microbiol. 2015, 6, 1196. [CrossRef] [PubMed]

67. Ngara, T.R.; Zhang, H. Recent Advances in Function-based Metagenomic Screening. Genom. Proteom. Bioinform. 2018, 16, 405-415. [CrossRef] [PubMed]

68. Lacerda Júnior, G.V.; Noronha, M.F.; de Sousa, S.T.P.; Cabral, L.; Domingos, D.F.; Sáber, M.L.; de Melo, I.S.; Oliveira, V.M. Potential of semiarid soil from Caatinga biome as a novel source for mining lignocellulose-degrading enzymes. FEMS Microbiol. Ecol. 2017. [CrossRef] [PubMed]

69. Žif̌ćáková, L.; Větrovský, T.; Lombard, V.; Henrissat, B.; Howe, A.; Baldrian, P. Feed in summer, rest in winter: Microbial carbon utilization in forest topsoil. Microbiome 2017, 5, 122. [CrossRef] [PubMed]

70. Wilhelm, R.C.; Singh, R.; Eltis, L.D.; Mohn, W.W. Bacterial contributions to delignification and lignocellulose degradation in forest soils with metagenomic and quantitative stable isotope probing. ISME J. 2019, 13, 413-429. [CrossRef] [PubMed]

71. Salam, L.B. Detection of carbohydrate-active enzymes and genes in a spent engine oil-perturbed agricultural soil. Bull. Natl. Res. Cent. 2018, 42, 10. [CrossRef]

72. Grieco, M.B.; Lopes, F.A.C.; Oliveira, L.S.; Tschoeke, D.A.; Popov, C.C.; De Souza, W.; Thompson, F.L. Metagenomic Analysis of the Whole Gut Microbiota in Brazilian Termitidae Termites Cornitermes cumulans, Cyrilliotermes strictinasus. Curr. Microbiol. 2019, 76, 687-697. [CrossRef]

73. Joynson, R.; Pritchard, L.; Osemwekha, E.; Ferry, N. Metagenomic analysis of the gut microbiome of the common black slug arion ater in search of novel lignocellulose degrading enzymes. Front. Microbiol. 2017, 8, 2181. [CrossRef]

74. Agamennone, V.; Le, N.G.; van Straalen, N.M.; Brouwer, A.; Roelofs, D. Antimicrobial activity and carbohydrate metabolism in the bacterial metagenome of the soil-living invertebrate Folsomia candida. Sci. Rep. 2019, 9, 7308. [CrossRef] [PubMed]

75. Jose, V.L.; Appoothy, T.; More, R.P.; Arun, A.S. Metagenomic insights into the rumen microbial fibrolytic enzymes in Indian crossbred cattle fed finger millet straw. AMB Express 2017, 7, 13. [CrossRef] [PubMed]

76. Gharechahi, J.; Salekdeh, G.H. A metagenomic analysis of the camel rumen's microbiome identifies the major microbes responsible for lignocellulose degradation and fermentation. Biotechnol. Biofuels 2018, 11, 216. [CrossRef] [PubMed]

77. Zhang, C.; Xu, B.; Lu, T.; Huang, Z. Metagenomic Analysis of the Fecal Microbiomes of Wild Asian Elephants Reveals Microflora and Enzymes that Mainly Digest Hemicellulose. J. Microbiol. Biotechnol. 2019, 29, 1255-1265. [CrossRef] [PubMed] 
78. Luo, C.; Li, Y.; Chen, Y.; Fu, C.; Long, W.; Xiao, X.; Liao, H.; Yang, Y. Bamboo lignocellulose degradation by gut symbiotic microbiota of the bamboo snout beetle Cyrtotrachelus buqueti. Biotechnol. Biofuels 2019, 12, 70. [CrossRef] [PubMed]

79. Tokuda, G. Plant Cell Wall Degradation in Insects: Recent Progress on Endogenous Enzymes Revealed by Multi-Omics Technologies, 1st ed.; Elsevier Ltd.: Amsterdam, The Netherlands, 2019; Volume 57, ISBN 9780128186602.

80. Do, T.H.; Nguyen, T.T.; Nguyen, T.N.; Le, Q.G.; Nguyen, C.; Kimura, K.; Truong, N.H. Mining biomass-degrading genes through Illumina-based de novo sequencing and metagenomic analysis of free-living bacteria in the gut of the lower termite Coptotermes gestroi harvested in Vietnam. J. Biosci. Bioeng. 2014, 118, 665-671. [CrossRef]

81. Brune, A. Symbiotic digestion of lignocellulose in termite guts. Nat. Rev. Microbiol. 2014, 12, 168-180. [CrossRef]

82. Zhou, J.; Duan, J.; Gao, M.; Wang, Y.; Wang, X.; Zhao, K. Diversity, Roles, and Biotechnological Applications of Symbiotic Microorganisms in the Gut of Termite. Curr. Microbiol. 2018, 76, 755-761. [CrossRef]

83. Suman, S.K.; Dhawaria, M.; Tripathi, D.; Raturi, V.; Adhikari, D.K.; Kanaujia, P.K. Investigation of lignin biodegradation by Trabulsiella sp. isolated from termite gut. Int. Biodeterior. Biodegrad. 2016, 112, 12-17. [CrossRef]

84. Chung, S.Y.; Maeda, M.; Song, E.; Horikoshi, K.; Kudo, T. A Gram-positive Polychlorinated Biphenyl-degrading Bacterium, Rhodococcus erythropolis Strain TA421, Isolated from a Termite Ecosystem. Biosci. Biotechnol. Biochem. 1994, 58, $2111-2113$. [CrossRef]

85. Le Roes-Hill, M.; Rohland, J.; Burton, S. Actinobacteria isolated from termite guts as a source of novel oxidative enzymes. Antonie Van Leeuwenhoek 2011, 100, 589-605. [CrossRef] [PubMed]

86. Terrapon, N.; Lombard, V.; Drula, E.; Coutinho, P.M.; Henrissat, B. The CAZy Database/the Carbohydrate-Active Enzyme (CAZy) Database: Principles and Usage Guidelines. In A Practical Guide to Using Glycomics Databases; Springer: Tokyo, Japan, 2017; pp. 117-131.

87. Su, L.; Yang, L.; Huang, S.; Su, X.; Li, Y.; Wang, F.; Wang, E.; Kang, N.; Xu, J.; Song, A. Comparative Gut Microbiomes of Four Species Representing the Higher and the Lower Termites. J. Insect Sci. 2016, 16, 1-9. [CrossRef] [PubMed]

88. Brune, A.; Ohkuma, M. Role of the termite gut microbiota in symbiotic digestion. In Biology of Termites: A Modern Synthesis; Springer: Dordrecht, The Netherlands, 2011; pp. 439-475, ISBN 9789048139767.

89. Bateman, A.; Coin, L.; Durbin, R.; Finn, R.D.; Hollich, V.; Griffiths-Jones, S.; Khanna, A.; Marshall, M.; Moxon, S.; Sonnhammer, E.L.L.; et al. The Pfam protein families database. Nucleic Acids Res. 2004, 32, D138-D141. [CrossRef] [PubMed]

90. Nagaraja, T.G. Microbiology of the Rumen. In Rumenology; Springer International Publishing: Cham, Switzerland, 2016; pp. 39-61, ISBN 9783319305332.

91. De Nardi, R.; Marchesini, G.; Li, S.; Khafipour, E.; Plaizier, K.J.C.; Gianesella, M. Metagenomic analysis of rumen microbial population in dairy heifers fed a high grain diet supplemented with dicarboxylic acids or polyphenols. BMC Vet. Res. 2016, 12, 1-9. [CrossRef] [PubMed]

92. Wang, L.; Hatem, A.; Catalyurek, U.V.; Morrison, M.; Yu, Z. Metagenomic insights into the carbohydrate-active enzymes carried by the microorganisms adhering to solid digesta in the rumen of cows. PLoS ONE 2013, 8, e78507. [CrossRef] [PubMed]

93. Kajikawa, H.; Kudo, H.; Kondo, T.; Jodai, K.; Honda, Y.; Kuwahara, M.; Watanabe, T. Degradation of benzyl ether bonds of lignin by ruminal microbes. FEMS Microbiol. Lett. 2000, 187, 15-20. [CrossRef] [PubMed]

94. Beloqui, A.; Pita, M.; Polaina, J.; Martínez-Arias, A.; Golyshina, O.V.; Zumárraga, M.; Yakimov, M.M.; García-Arellano, H.; Alcalde, M.; Fernández, V.M.; et al. Novel polyphenol oxidase mined from a metagenome expression library of bovine rumen: Biochemical properties, structural analysis, and phylogenetic relationships. J. Biol. Chem. 2006, 281, 22933-22942. [CrossRef]

95. Ufarté, L.; Potocki-Veronese, G.; Cecchini, D.; Tauzin, A.S.; Rizzo, A.; Morgavi, D.P.; Cathala, B.; Moreau, C.; Cleret, M.; Robe, P.; et al. Highly promiscuous oxidases discovered in the bovine rumen microbiome. Front. Microbiol. 2018, 9, 1-12. [CrossRef]

96. Carlos, C.; Fan, H.; Currie, C.R. Substrate shift reveals roles for members of bacterial consortia in degradation of plant cell wall polymers. Front. Microbiol. 2018, 9, 364. [CrossRef]

97. Moraes, E.C.; Alvarez, T.M.; Persinoti, G.F.; Tomazetto, G.; Brenelli, L.B.; Paixão, D.A.A.; Ematsu, G.C.; Aricetti, J.A.; Caldana, C.; Dixon, N.; et al. Lignolytic-consortium omics analyses reveal novel genomes and pathways involved in lignin modification and valorization. Biotechnol. Biofuels 2018, 11, 75. [CrossRef]

98. Jiménez, D.J.; de Lima Brossi, M.J.; Schückel, J.; Kračun, S.K.; Willats, W.G.T.; van Elsas, J.D. Characterization of three plant biomass-degrading microbial consortia by metagenomics- and metasecretomics-based approaches. Appl. Microbiol. Biotechnol. 2016, 100, 10463-10477. [CrossRef] [PubMed]

99. Zhu, N.; Yang, J.; Ji, L.; Liu, J.; Yang, Y.; Yuan, H. Metagenomic and metaproteomic analyses of a corn stover-adapted microbial consortium EMSD5 reveal its taxonomic and enzymatic basis for degrading lignocellulose. Biotechnol. Biofuels 2016, 9, 243. [CrossRef] [PubMed]

100. Wang, C.; Dong, D.; Wang, H.; Müller, K.; Qin, Y.; Wang, H.; Wu, W. Metagenomic analysis of microbial consortia enriched from compost: New insights into the role of Actinobacteria in lignocellulose decomposition. Biotechnol. Biofuels 2016, 9, 22. [CrossRef] [PubMed]

101. D’haeseleer, P.; Gladden, J.M.; Allgaier, M.; Chain, P.S.G.; Tringe, S.G.; Malfatti, S.A.; Aldrich, J.T.; Nicora, C.D.; Robinson, E.W.; Paša-Tolić, L.; et al. Proteogenomic Analysis of a Thermophilic Bacterial Consortium Adapted to Deconstruct Switchgrass. PLoS ONE 2013, 8, e68465. [CrossRef] [PubMed] 
102. Lemos, L.N.; Pereira, R.V.; Quaggio, R.B.; Martins, L.F.; Moura, L.M.S.; da Silva, A.R.; Antunes, L.P.; da Silva, A.M.; Setubal, J.C. Genome-centric analysis of a thermophilic and cellulolytic bacterial consortium derived from composting. Front. Microbiol. 2017, 8, 644. [CrossRef] [PubMed]

103. Aguiar-Pulido, V.; Huang, W.; Suarez-Ulloa, V.; Cickovski, T.; Mathee, K.; Narasimhan, G. Metagenomics, metatranscriptomics, and metabolomics approaches for microbiome analysis. Evol. Bioinforma. 2016, 12, 5-16. [CrossRef] [PubMed]

104. Hassa, J.; Maus, I.; Off, S.; Pühler, A.; Scherer, P.; Klocke, M.; Schlüter, A. Metagenome, metatranscriptome, and metaproteome approaches unraveled compositions and functional relationships of microbial communities residing in biogas plants. Appl. Microbiol. Biotechnol. 2018, 102, 5045-5063. [CrossRef]

105. Antunes, L.P.; Martins, L.F.; Pereira, R.V.; Thomas, A.M.; Barbosa, D.; Lemos, L.N.; Silva, G.M.M.; Moura, L.M.S.; Epamino, G.W.C.; Digiampietri, L.A.; et al. Microbial community structure and dynamics in thermophilic composting viewed through metagenomics and metatranscriptomics. Sci. Rep. 2016, 6, 38915. [CrossRef] [PubMed]

106. Jiménez, D.J.; De Mares, M.C.; Salles, J.F. Temporal expression dynamics of plant biomass-degrading enzymes by a synthetic bacterial consortium growing on sugarcane bagasse. Front. Microbiol. 2018, 9, 299. [CrossRef]

107. Tokuda, G.; Mikaelyan, A.; Fukui, C.; Matsuura, Y.; Watanabe, H.; Fujishima, M. Fiber-associated spirochetes are major agents of hemicellulose degradation in the hindgut of wood-feeding higher termites. Proc. Natl. Acad. Sci. USA 2018, 115, E11996-E12004. [CrossRef]

108. Marynowska, M.; Goux, X.; Sillam-Dussès, D.; Rouland-Lefèvre, C.; Roisin, Y.; Delfosse, P.; Calusinska, M. Optimization of a metatranscriptomic approach to study the lignocellulolytic potential of the higher termite gut microbiome. BMC Genom. 2017, 18, 681. [CrossRef] [PubMed]

109. Singh, R.; Bennett, J.P.; Gupta, M.; Sharma, M.; Eqbal, D.; Alessi, A.M.; Dowle, A.A.; McQueen-Mason, S.J.; Bruce, N.C.; Yazdani, S.S. Mining the biomass deconstructing capabilities of rice yellow stem borer symbionts. Biotechnol. Biofuels 2019, 12, 265. [CrossRef] [PubMed]

110. Kleiner, M. Metaproteomics: Much More than Measuring Gene Expression in Microbial Communities. mSystems 2019, 4, 1-6. [CrossRef] [PubMed]

111. Wang, Y.; Zhou, Y.; Xiao, X.; Zheng, J.; Zhou, H. Metaproteomics: A strategy to study the taxonomy and functionality of the gut microbiota. J. Proteom. 2020, 219, 103737. [CrossRef] [PubMed]

112. Zhou, H.; Guo, W.; Xu, B.; Teng, Z.; Tao, D.; Lou, Y.; Gao, Y. Screening and identification of lignin-degrading bacteria in termite gut and the construction of LiP-expressing recombinant Lactococcus lactis. Microb. Pathog. 2017, 112, 63-69. [CrossRef] [PubMed]

113. Song, W.; Han, X.; Qian, Y.; Liu, G.; Yao, G.; Zhong, Y.; Qu, Y.; Han, X.; Qu, Y.; Zhong, Y.; et al. Proteomic analysis of the biomass hydrolytic potentials of Penicillium oxalicum lignocellulolytic enzyme system. Biotechnol. Biofuels 2016, 9, 68. [CrossRef] [PubMed]

114. Gómez-Mendoza, D.P.; Junqueira, M.; Do Vale, L.H.F.; Domont, G.B.; Ferreira Filho, E.X.; De Sousa, M.V.; Ricart, C.A.O. Secretomic survey of trichoderma harzianum grown on plant biomass substrates. J. Proteome Res. 2014, 13, 1810-1822. [CrossRef] [PubMed]

115. Rocha-Martín, J.; Martínez-Bernal, C.; Zamorano, L.S.; Reyes-Sosa, F.M.; Díez, G.B. Inhibition of enzymatic hydrolysis of pretreated corn stover and sugar cane straw by laccases. Process Biochem. 2018, 67, 88-91. [CrossRef]

116. Arias, M.E.; Rodrı, J.; Soliveri, J.; Ball, A.S.; Herna, M. Kraft Pulp Biobleaching and Mediated Oxidation of a Nonphenolic Substrate by Laccase from Streptomyces cyaneus CECT 3335. Appl. Environ. Microbiol. 2003, 69, 1953-1958. [CrossRef] 